\title{
O PRINCÍPIO DA IGUALDADE EM PERSPECTIVA HISTÓRICA: CONTEÚDO, ALCANCE E DIREÇÕES
}

\author{
MAREN GUIMARÃES TABORDA*
}

\begin{abstract}
"A liberdade e a igualdade dos homens não são um dado de fato, mas um ideal a perseguir; não são uma existência, mas um valor, não são um ser, mas um dever-ser".
\end{abstract}

Bobbio, A Era dos Direitos.

Introdução. I) - A Igualdade como Justiça. A - O Justo como nominón; $B$ - O Justo como íson; II) - O Mandamento Constitucional da Igualdade. A - A Igualdade Formal; B - Em direção à Igualdade Material; $C-A$ Igualdade de "chances"; $D-A$ Igualdade "na" lei; III) - O Princípio Isonômico no Ordenamento Jurídico Brasileiro. A $-O$ legislador como destinatários; $B-A$ extensão do Princípio da Igualdade no Direito Brasileiro. Conclusāo.

\section{Introdução}

Rico e fecundo é o tema da igualdade, na história do pensamento jurídico-político ocidental, ${ }^{\prime}$ principalmente porque a realidade sensível nos indica que a regra, entre os seres vivos, é a desigualdade: os recentes avanços da ciência e da técnica mostram não haver, na natureza, dois indivíduos idênticos dentre as espécies que compartilham o planeta. O rastreamento do DNA humano e das espécies vivas são bem a prova desse fato e, diuturnamente, colocam novos problemas a serem resol-

1 "Pensar em igualdade é pensar em justiça na linha de análise aristotélica, retomada pela Escolástica e por todas as correntes posteriores, de Hobbes e Rousseau a Marx e Rawls; é redefinir as relaçōes entre pessoas e as normas jurídicas; é indagar da lei e da generalidade da lei". Jorge MIRANDA, Manual de Direito Constitucional, Tomo IV, $2^{\mathrm{a}}$ ediçāo, Coimbra Editora, Coimbra, 1993, p. 201.

* Professora de História do Direito da UNISINOS e de Filosofia do Direito da UFRGS.

R. Dir. Adm.,

Rio de Janeiro, 211: 241-269, jan./mar. 1998 
vidos do ponto de vista do Direito (regulação histórico-objetiva da conduta social). Porém, se pensarmos em um termo relacional, ${ }^{2}$ uma propriedade natural e uma situação fática, ${ }^{3}$ um critério qualquer através do qual possamos estabelecer uma comparação, então poderemos emitir enunciados do tipo: "os homens são iguais porque possuem órgãos e tecidos constitutivos idênticos" (tanto que os transplantes de órgãos são possíveis) e, neste caso, teremos igualdade relacionada ao critério constituição física, em determinados aspectos: constituição dos órgãos e tecidos formativos, ou, ainda, "os homens são iguais porque todos feitos à imagem e semelhança de Deus", onde o critério de comparação é ter uma mesma origem abstrata: Deus. Daí temos que, relacionados os critérios com os entes que se comparam, as combinações são múltiplas, variáveis e infinitas. Quem discorda o fato de ser a humanidade, em maior ou menor medida, comparável a uma ameba ou a uma estrela? Os critérios comparativos são, nestes casos, os aminoácidos e o hidrogênio, respectivamente.

Sendo assim, podemos dizer que a igualdade só é uma propriedade ou uma qualidade em si mesma, se se referir "a um determinado tipo de relação entre os entes que fazem parte da categoria abstrata humanidade" ${ }^{4} \mathrm{e}$ se abstrairmos das desigualdades fáticas existentes entre os seres humanos, tais como as que os diferenciam entre homens e mulheres, negros, brancos, amarelos ou vermelhos, pobres ou ricos, mais aptos ou menos aptos para determinadas tarefas, feios ou bonitos etc., para equiparálos em algum sentido ou em relação a um critério previamente determinado. Daí, tem sentido falar "todos os homens são iguais" (feita esta abstração), na mesma medida em que carece totalmente de sentido falar "Luís é igual", pois sempre restarão as perguntas: “a quem? em quê?". Esses "quem" e "quê" são as notas diferenciadoras da idéia de igualdade nas diversas disciplinas do pensamento humano.

A idéia de igualdade indica, volta e meia "uma realidade ou esperança, uma verdade natural ou um programa revolucionário" 5 , ou, ainda, um problema de justiça social, sendo, no plano jurídico-político, significativa e permanentemente discutida, indicando ora um ideal a ser concretizado, ora um dos alicerces dos ordenamentos jurídicos ocidentais, consubstanciado na aplicação permanente da "regra de justiça", que determina o tratamento igual (igual pelo igual, diverso pelo diverso) e põe o problema de saber-se quais são as desigualdades irrelevantes para o tratamento dos homens $^{6}$ e não uma idéia vazia, carente de sentido, como afirmam alguns juristas. ${ }^{7}$

2 Cf. BOBBIO, Norberto. Igualdade e Liberdade. Ediouro, Rio de Janeiro, 1996, p. 7: "Liberdade indica um estado; igualdade, uma relaçāo."

3 ALEXY, Robert. Teoria de los Derechos Fundamentales. Centro de Estudios Constitucionales. Madrid, 1993, p. 385

4 BOBBIO. Nota 2, p. 12.

5 CURCIO, Carlo. EGUAGLIANZA (douttrine generale). Enciclopedia del Diritto. Vol. XIV. Giufré, Milāo, 1964, p. 510.

6 KELSEN, H., aduz serem as diversas normas de justiça normas referidas "ao modo de tratar os homens", in: O problema da Justiça, Martins Fontes, Sāo Paulo, 1993, p. 29.

7 Ver FEREIRA PINTO, Maria da Glória, in: Princípio da Igualdade-fórmula vazia ou fórmula "carregada" de sentido? Onde a autora discute as idéias de Peter Westen (The empty idea of equality). Boletim do Ministério da Justiça, n² 358; julho, 1986, Lisboa, pp. 19/64. 
Em termos políticos, a idéia de igualdade sempre foi relacionada à de liberdade. Foi na "polis" grega que o homem se descobriu hómoioi (semelhante) e, depois, de maneira abstrata, como isoi (igual), na condução dos negócios públicos, porque, apesar das diferenças existentes no plano da realidade da vida social (diferenças de classes, de riqueza), conseguiu abstrair-se dessa realidade e se conceber, no plano político, como unidade permutável " no interior de um sistema cuja lei é o equilíbrio, cuja norma é a igualdade. Essa imagem do mundo humano encontrará no século VI sua expressão rigorosa em um conceito, o de isonomia: igual participação de todos os cidadãos no exercício do poder" ${ }^{8}$ ou, especificamente, igualdade das leis para todos (ísos = igual; nómos = lei). Despiciendo ressaltar que equivalentes, para os gregos, eram tão-somente os cidadãos, os homens livres: as mulheres, até o raiar do século $\mathrm{XX}$, sempre foram consideradas equivalentes ou "iguais" às crianças, não participando da vida política e merecendo tutela. A liberdade vinha associada a esta participação na vida do Estado, ${ }^{9}$ que era mestre e senhor da vida dos cidadãos ou a "uma forma de organização política em que os cidadãos viviam juntos em condições de não-mando, sem uma distinção entre governantes e governados" ${ }^{10}$ e só mais tarde foi concebida como a faculdade do homem de obedecer somente a si mesmo ou, ainda, a ausência de qualquer vinculação jurídica ou a esfera onde não existem comandos ou proibições. "A polis era dona e senhora do corpo e da alma dos homens livres: o corpo - arma da cidade - se educava para a guerra, com a ginástica, e a alma de cada um era educada pela filosofia, para atender a fins coletivos. Destarte, em sendo os homens desiguais por natureza, necessitavam desta instituição artificial - a polis - para se tornarem iguais, e a igualdade (isonomia) só existia e tinha sentido no campo da atividade política, onde os homens conviviam como cidadãos e não como pessoas privadas.

A idéia de que "todos" os homens são iguais, independentemente de sua origem social, gênero, idade etc. — pedra angular da ética cristã — só recebeu formulação concreta, em termos jurídico-políticos, na era das grandes revoluçōes liberais, mais precisamente com a "Virgínia Bill of Rights", de $12.6 .1776^{12}$ e, ainda, assim, não

8 VERNANT, Jean-Pierre, As origens do pensamento grego, $2^{\mathrm{a}}$ ed., DIFEL, Rio de Janeiro, 1977, p. 42.

9 Sobre os dois tipos de liberdade política, ver CONSTANT, Benjamin. Da liberdade dos Antigos comparada d̀ dos Modernos. Revista de Filosofia Política, n² 2, L\&PM Editores, Porto Alegre, 1984; BOBBIO, Norberto. Kant e as duas Liberdades, in: Ensaios Escolhidos, C.H. Cardim Editora, São Paulo, s/d.; HABA, Enrique P. Droits de l'homme, libertés individuelles et rationalité juridique (Quelques remarques méthodologiques), Archives de Philosophie du Droit, Tome 25 (la loi), Sirey, Paris.

10 ARENDT, Hannah, Da Revolução. Editora da UNB em co-ediçāo com Editora Ática, Brasilia, 1990, p. 24.

11 Cf. KELSEN, Hans. Teoria Pura do Direito. Armênio Amado Editor, $4^{\mathrm{a}}$ ed. Coimbra, 1979, pp. 72 e ss.

12 “... That all men are by nature equally free and independent, and have and have certain inherent rights”... cf. CLAVERO, Bartolomé, Institucion Historica del Derecho, Marcial Pons, Madrid, 1992, p. 203 (textos). Ainda sobre a história das Declaraçōes de Direitos, ver: BOBBIO, Norterto. A Era dos Direitos. Editora Campos, São Paulo, 1992; CANOTILHO, J. J. Gomes. Direito Constitucional. Almedina, Coimbra, 1993; MIRANDA, Jorge, Manual de Direito Constitucional, Tomo IV, Coimbra Editora, Coimbra, 1993, Os Direitos Fundamentais - sua dimensão individual e social, Cadernos de Direito 
se tratava de igualdade política plena, pois que não se reconhecia direito de sufrágio às mulheres e trabalhadores, num claro exemplo de que este "todos" eram apenas alguns: os burgueses proprietários, pais de família — modelo de cidadão à moda romana. ${ }^{13}$

Foi também entre os gregos (pitagóricos) que nasceu a noção de que a igualdade é justiça. Para eles, a harmonia e regularidade do universo, concebido como kosmos (totalidade ordenada), se traduz na esfera humana em uma correlação de condutas, e a justiça (dikê) se caracteriza como uma relação de igualdade entre dois termos, como por exemplo, uma injúria e sua reparação. Havendo um desequilíbrio no kosmos, é tarefa da Justiça reintroduzí-lo. ${ }^{14}$ Esta idéia perpassa todo o pensamento grego, até sua mais completa e última formulação, com Aristóteles, na "Ética à Nicômano", que identifica a justiça como uma "virtude completa" ${ }^{15}$ e social, ${ }^{16}$ um meio-termo entre o muito e o pouco.

Constitucional e Ciência Política, RT, São Paulo, 1992 e Textos Históricos de Direito Constitucional, Imprensa Nacional - Casa da Moeda, Lisboa, 1990; PONTES DE MIRANDA, Francisco Cavalcanti. Democracia. Liberdade, Igualdade (Os Três Caminhos). $2^{\mathbf{a}}$ ed. Saraiva, São Paulo, 1979; FERREIRA FILHO, Manoel Gonçalves. Direitos Humanos Fundamentais. Saraiva, São Paulo, 1995; RIVERO, Jean. Les Libertés Publiques, Presse Universitaire de France, I ed., Paris, 1973; HEYMANN-DOAT, Arlette. Libertés publiques et droits de l'homme, $3^{2}$ ed., L.G.D.J.), Paris, 1994.

13 O processo revolução/declaração de Direitos/codificação civil (CLAVERO, Bartolomé, Condificaciön y. Constitución: Paradigmas de un Binomio, Quadermi Fiorentini, XVIII, Florença, 1992, pp. 79/113) foi a unificação do sujeito destinatário da ordem jurídica e não só um processo de unificação da fonte de produção jurídica (monopolização pelo Estado), semelhante ao que ocorreu outras vezes na história do Direito Ocidental, como, por exemplo, na codificação do Direito Romano promovida por Justiniano. Sobre o tema: BOBBIO, N. O Positivismo Jurídico - Liçōes de Filosofia do Direito, f́cone, São Paulo, 1995; GROSSI, Paolo, Absolutismo Juridico y Derecho Privado en el siglo XIX, Universidad Autónoma de Barcelona, 1991; TARELLO, Giovanni. Storia della cultura giuridica moderna, Società editrice il Mulino, Milāo, 1987; KUNKEL, Wolfgang, Historia del Derecho Romano, Editorial Ariel, Barcelona, 1991; MARTINS COSTA, Judith Hofmeister, Sistema e Cláusula Geral (A Boa fé objetiva no processo obrigacional), $1^{\circ}$ vol. Tese de Doutorado em Direito Civil, USP, Faculdade de Direito, São Paulo, 1996; WIEACKER, Franz, Historia do Direito Privado Moderno, Fundaçāo Calouste Gulbenkian, Lisboa, 1980; GAUDEMET, Jean. El Milagro Romano, in: El Mediterrâneo BRAUDEL, Fernan \& Outros, Epasa Calpe, Madrid, 1987; IGLESIAS, Juan. Derecho Romano (Historia y Instituciones), Editorial Ariel, Barcelona, 1994.

14 Essa idéia aparece em Heráclito, para quem a Justiça é uma luta, um perpétuo vir a ser. O fluxo ininterrupto do vir a ser é presidido pela lei universal e eterna do Logos, que introduz a harmonia e mantêm os corpos celestes em sua órbita. A Justiça (dikê) poderia usar suas servidoras (Eríneas, de eris, luta; vingadoras) para obrigar o sol (helios, ou o carro de Apolo) a voltar para sua órbita, caso dela se afastasse. Sobre o pensamento e mitologia grego ver. TRUYOL Y SERRA, Antonio. Historia de la Filosofia del Derecho y del Estado. Vol. I. Alizanza Universidad Textos, $10^{2}$ ed., Madrid, 1992; FASSÒ, Guido. Historia de la Filosofia del Derecho, Vol. I. Ediciones Piramides, S.A. Madrid, s/d; Os Pré-Socráticos. Coleção "Os Pensadores", Abril Cultural, São Paulo, 1979; BURKERT, Walter. Religiāo Grega na Época Clássica e Arcaica, Fundaçāo Calouste Gulbenkian, Lisboa, 1993; FRAZER, Sir James George. $O$ Ramo de Ouro. Texto editado por Mary Douglas. Guanabara Koogan S.A., Rio de Janeiro, 1982; BRANDĀO, Junito de Souza. Mitologia Grega, Vols. I. II e III. Vozes, Petrópolis, 1987; PANIÁGUA, José Maria Rodriguez. Historia del Pensamiento Jurídico Vol. I, Universidad Complutense - Facultad de Derecho, Seccion de Publicaciones, Madrid, 1988; JAEGER, Werner. PAIDEIA: los ideales de la cultura grega, Fondo de Cultura Econômica, México, 1957.

15 ARISTÓTELES. Ética a Nicômano. Coleçāo “Os Pensadores”, Abril Cultural, São Paulo, 1979, p. 122. 
Não se pode perder de vista, também, que a idéia de igualdade sempre se apresentou ao pensamento humano conectada e misturada com outras idéias análogas, tais como a de liberdade, justiça, humanidade etc., e com significados e valores muito diversos. Se a igualdade é um valor, como reiteradamente afirmam os filósofos e juristas, é, necessariamente, um valor relativo e só neste plano - o da relatividade — tem sentido ${ }^{17}$. Os gregos, por exemplo, distinguiam várias espécies de igualdade: como meio-termo proporcional entre o muito e o pouco, a perda e o ganho, igualdade diante da lei (que significava também igualdade de exercer cargos públicos), ou, ainda, como igual direito de exprimir pensamento. Nesta última acepção, a idéia vinha conectada com a liberdade política, como já referido. Daí decorre o fato lembrado por Bobbio, de que "a esfera de aplicação da justiça, ou da igualdade social e politicamente relevante, é a das relaçōes sociais, ou dos indivíduos com o grupo (e vice-versa)". ${ }^{18}$

Em conexão com a idéia de liberdade, a igualdade entre os homens surge na razão direta da consideração do homem como "pessoa", que, em sua singularidade, deve ser livre e "enquanto ser social, deve estar com os demais indivíduos numa relação de igualdade", ${ }^{19}$ ou, como diz Castanheira Neves ${ }^{20}$ "se a igualdade se pode dizer a condição social da liberdade, a liberdade é uma possibilidade pessoal que só será universal se todos nela se reconhecerem iguais e se nenhum for já privilegiado já diminuído nessa possibilidade". Nesse sentido, é que diz-se ser a igualdade uma relação desejável entre indivíduos livres; não um ser, mas um dever-ser, já que uma sociedade em que todos são livres e iguais em uma mesma medida é um estado apenas imaginado, hipotético. Liberdade e igualdade constituem, assim, o conteúdo material do ideal da Justiça, uma vez que a liberdade é um valor para o homem, enquanto indivíduo, e igualdade um bem ou valor para o homem enquanto ser genérico, como um ser pertencente a determinada classe ou grupo - a humanidade. O grau de liberdade existente em uma sociedade é proporcional ao número de indivíduos livres, subentendendo "que todos os indivíduos têm igual valor político e que todos têm o mesmo direito à liberdade, ou seja, o mesmo direito de que a

16 "Em certo sentido, chamamos justos aqueles atos que tendem a produzir e a preservar, para a sociedade política, a felicidade e os elementos que a compōem" (...) justiça é, portanto, uma virtude completa, porém não em absoluto e sim em relação ao nosso próximo". Com essas palavras, Aristóteles deixa claro, no texto ora comentado, ser a Justiça uma virtude relacional: a Justiça é a alteridade e só se realiza socialmente. Nota 15, p. 122.

17 Sobre a relatividade dos valores, ver KELSEN, Hans. Teoria Pura do Direito e $O$ problema da Justiça; CANOTILHO, J. J. Gomes. Direito Constitucional; PECES-BARBA, Gregório. La Constitución Espa * ñola de 1978 - Un estudio de Derecho y Política; MIRANDA CARVALHO; Virgílio de Jesus Miranda, Os Valores Constitucionais Fundamentais: Esbofo de uma análise axiológico-normativa; VILLEY, Michel. Metodo, Fuentes y Lenguage Juridicos; ENGISH, Karl, Introdução ao Pensamento Jurídico. CANARIS, Wilhelm Claus. Pensamento Sistemático e Conceito de Sistema na Ciência do Direito; BOBBIO, Norberto. Teoria General del Derecho, O Positivismo Jurídico, A Era dos Direitos.

18 BOBBIO, nota 2, p. 16.

19 BOBBIO, nota 2, p. 7.

20 In: Justiça e Direito. Boletim da Faculdade de Direito da Universidade de Coimbra, Vol. VI., 1975, p. 260. 
vontade coletiva esteja em concordância com a sua vontade individual". ${ }^{21}$ Essa noção moderna da igualdade é o resultado de duas linhas de pensamentos filosóficos diferentes sobre o seu valor: a primeira, assente em uma tradição que remonta Aristóteles, em que aparece ligada à idéia de justiça (I), e a segunda, conexa com o constitucionalismo surgido nos séculos XVII e XVIII, na Europa Ocidental (II), em que aparece como exigência política fundamental e verdadeiro axioma jurídico-político que todas as Constituições dos Estados modernos acolheram e que, de certa forma, também pode ser relacionada, em última instância, com a idéia aristotélica de "justiça política".

Nesse plano (jurídico-político), podemos partir da premissa de que a igualdade entre os homens é mais um programa a realizar do que um fato dado que tenha de ser levado em conta para a aplicação do ordenamento, face às desigualdades históricas entre eles. Verificar o conteúdo da idéia de igualdade, quais as desigualdades relativas a que qualidades devem ser consideradas e quais desigualdades relativas a tantas outras não devem ser levadas em conta, e analisar os critérios permitidos para tratamento desigual, passa, primeiro, por retraçar, nos seus aspectos mais importantes, o "iter" histórico e os vários significados e desdobramentos do princípio da igualdade constitucional. A partir daí, poderemos descrever, de modo seguro, o tratamento dado ao princípio isonômico no Ordenamento Jurídico Brasileiro (III), suas direções e alcance. A título de conclusão, resta a consideração de que o Princípio da Igualdade é, na maior parte dos ordenamentos jurídicos ocidentais, um princípio fundante e estruturador de toda a ordem jurídica, sendo impositivo em todos os seus campos, ao não assegurar aos indivíduos nenhuma situação jurídica específica, mas garanti-lo contra "toda má utilização que possa ser feita" ${ }^{22}$. Registra-se, ainda, ser a igualdade jurídica entre homens e mulheres um dos campos mais difíceis e controvertidos de aplicação do princípio constitucional da isonomia, em face de ser esta equiparação muito recente na história da cultura e, principalmente, das injustiças e discriminações cristalizadas, e ainda presentes, no âmbito do Direito Privado, isto é, da regulação da família. Constata-se, finalmente, que o difícil não é o impossível, pois muito já se avançou. Há que se avançar mais para que esta equalização seja plena, principalmente para além do campo jurídico. Isto não é, por ora, objeto de nosso estudo, até por considerarmos ser esta tarefa mais de economistas, políticos e sociólogos que de juristas.

\section{A Igualdade como Justiça}

\section{A. O justo como nóminon}

Na Antiguidade, inicialmente, justiça era ligada a uma idéia transcendente de harmonia cósmica, não humana (dikê), em uma visão que concebe a ordem do

21 KELSEN, H. Teoria Geral do Direito e do Estado. Martins Fontes, Sāo Paulo, 1992, p. 281.

22 BASTOS, Celso Ribeiro, Curso de Direito Constitucional, $14^{12}$ ediçāo, Saraiva, São Paulo, 1992, p. 169. 
universo como projeção e reflexo da ordem social. Com o surgimento dos sofistas, passou-se a considerar a justiça como ordem especificamente humana, e um de seus significados mais importantes foi resumido por Aristóteles nos seguintes termos: justo é o que assim é estabelecido pelas leis e costumes do Estado, por ato de autoridade ou em virtude de conveniência ou convenção (justiça política ou "justo legal"), e que é encontrado "entre os homens que vivem em comum tendo em vista a auto-suficiência, homens que são livres e iguais, quer aritmeticamente, quer proporcionalmente", ${ }^{23}$ ou o que tem, em todas as partes, a mesma força "e não existe em razão de pensarem o homens deste ou daquele modo" (justo natural ou justo absoluto). ${ }^{24}$ Assim, Aristóteles concebeu, previamente, como justo o homem que respeita as leis, a ação realiza em conformidade com a lei e as próprias leis (humanas), porquanto estas estão em conformidade com as leis superiores - naturais ou divinas: é o significado do justo como legitimidade, como nóminon ${ }^{25}$ Nesse particular, é importante salientar que Aristóteles ainda pensou ser a justiça legal "corrigida" pela epiéikeia (conveniência, adaptação, traduzida pelos romano por aequitas), uma outra espécie de justiça que faz a adaptação entre o justo legal e o justo natural, porquanto aquele, formulado em termos de extrema generalidade, para assegurar a liberdade $e$ a igualdade de todos diante da lei, pode, muitas vezes, ser deficiente e não assegurar a justiça (sendo mesmo um obstáculo), precisamente porque não tem em conta os casos concretos. Atender a estes casos é a missão da epiéikeia. ${ }^{26}$

\section{B. O justo como ison}

Outro significado presente é o de justo como íson (igualdade), como virtude particular, ou, ainda, como um ponto intermediário, um meio-termo, com as várias distinções que se tornaram tradicionais. A primeira espécie de justiça particular é a que se manifesta "na distribuições de honras, de dinheiro ou das outras coisas" 27 que se tenha que distribuir na sociedade política. Aqui, estamos diante do problema de atribuir vantagens ou desvantagens, direitos ou deveres aos indivíduos pertencentes a uma determinada categoria, equiparando-se pessoas (homens e mulheres na

23 ARISTÓTELES. Nota 15, p. 130: “... o que estamos procurando nāo é apenas aquilo que $\epsilon$ justo incondicionalmente, mas também a justiça política. Esta é encontrada entre homens que vivem em comum tendo em vista a auto-suficiência, homens que são livres e iguais, quer proporcionalmente, que aritmeticamente, de modo que entre os que não preenchem esta condição não existe justiça política, mas justiça num sentido especial e por analogia".

24 ARISTÓTELES. Nota 15, p. 131. Essa passagem é muito discutida e de difícil compreensão, pois Aristóteles afirma não existir o justo natural porque, na natureza, só o divino é absolutamente imutável. Assim, o que diferencia o justo legal do justo natural é o grau de mutaçāo ("por natureza, a mảo direita é mais forte; e no entanto, é possível que todos os homens venham a tornar-se ambidestros") e o fato de ser o justo legal uma espécie de medida, que dá forma e consistência ao justo natural, como as vasilhas e pacotes de mercadorias, que são as medidas reais e não ideais.

25 ver FASSÒ, Guido. Nota 14, pp. 59 e ss.

ARISTÓTELES. Nota 15, pp. $136 / 137$.

ARISTÓTELES. Nota 15, p. 124. 
relação conjugal; trabalhadores e patrões na relação de trabalho), ${ }^{28}$ em relação a determinadas coisas: os objetos distribuídos (relação entre o todo e as partes). Nesse passo, ensina Aristóteles:

"Ora, a igualdade implica pelo menos duas coisas. $O$ justo, por conseguinte, deve ser ao mesmo tempo intermediário, igual e relativo (isto é, para certas pessoas). $E$, como intermediário, deve encontrar-se entre certas coisas (as quais são, respectivamente, maiores e menores); como igual, envolve duas coisas; e, como justo, o é para certas pessoas. $O$ justo, pois, envolve pelo menos quatro termos, porquanto duas são as pessoas para quem ele é de fato justo, e duas são as coisas em que se manifesta - os objetos distribuidos". ${ }^{29}$

Nesse caso, o da distribuição (que a tradição posterior chamou de "justiça distributiva), que tem lugar na relação entre o todo e as partes, qual o melhor critério do justo? Aristóteles responde ser o critério do mérito de cada um, fazendo-se, portanto, uma medição pessoal. Vai mais além, ao afirmar que os democratas identificam esse mérito "com a condição de homem livre, os partidários da oligarquia com a riqueza (ou com a nobreza de nascimento), e os partidários da aristocracia com a excelência" ${ }^{30} \mathrm{~A}$ justiça vem, então, definida como uma proporção geométrica e a violação da proporção assim estabelecida é a injustiça.

Já a segunda espécie de justiça como virtude particular - a corretiva - que a tradição jurídica chamou de "justiça comutativa" ou "retributiva", ${ }^{31}$ é aquela que desempenha papel corretivo nas transações entre os indivíduos, ou que preside às trocas. O problema da igualdade é aqui visto como uma situação de equivalência de coisas, em uma relação bilateral e recíproca: uma proporção aritmética, uma retribuição proporcional pela qual "a cidade se mantém unida". ${ }^{32}$ Esta é justiça que preside às trocas e o critério da equalização é a proporção entre o que se dá ou recebe: justo é receber cada um o que é seu, ou o intermédio entre a perda e o ganho: "relação entre mercadorias e preço, relação entre pagamento e trabalho, relação entre dano e indenização, relação entre crime e castigo". ${ }^{33}$ Aqui, a justiça que dá a todos na mesma medida é uma proporção aritmética, que preside as relações de troca voluntárias, se derivarem dos contratos, e involuntárias, se forem produtos de atos ilícitos. Essa diferença resultará na igualdade que esta justiça realiza: pelas partes, diretamente, ou pelo juiz.

28 Cf. BOBBIO. Nota 2, p. 17.

29 Nota 15, p. 125.

30 Nota 15, p. 125.

31 BOBBIO. Nota 2, p. 17.

32 ARISTÓTELES. Nota 15, p. 128.

33 BOBBIO. Nota 2, p. 17. KELSEN denomina Vergeltung ou princípio retributivo aquele segundo o qual se pode reagir a uma determinada conduta com um prêmio ou um castigo, isto $e$, uma sanção em sentido amplo. "Na medida em que o direito é uma ordem estatuidora de sançōes e as sançōes consistem na aplicação coativa de um mal como reação contra um ilícito, o direito - todo o direito - corresponde ao princípio da retribuiçāo. Mas o princípio retributivo postula também um prêmio para o merecimento e é, assim, uma aplicação do preceito moral da gratidão", nota 6, p. 32; ver também Teoria Pura do Direito (nota 11), p. 49 e Teoria Geral do Direito e do Estado, Martins Fontes, São Paulo, 1992, p. 23. 
Pois bem: dar a cada um o que é seu, tratar igualmente os iguais e desigualmente os desiguais, significa aceitar as desigualdades co-naturais à idéia de homem imanentes e inafastáveis - incorporá-las ao tratamento jurídico dado à desigualdade e decidir sobre a diferença essencial entre a igualdade desejável ou indesejável, do ponto de vista político. Isso, contudo, coloca vários problemas, pois, como saber o que é o "seu" de cada um? O mérito, a capacidade, o talento, ou a necessidade, já que nenhum desses critérios tem valor absoluto e é perfeitamente objetivo? Em algumas situações, um é mais aplicado que outro, o que significa que a máxima ${ }^{34}$ "a cada um o que é seu" não enuncia nenhum critério objetivo e sim abrange e tolera todos eles, dependendo da situação concreta.

Discorrendo sobre a idéia da justiça como suum cuique tribuere, ${ }^{35} \mathrm{Kelsen}^{36}$ assevera que essa norma de justiça só pode ser aplicada desde que uma ordem normativa, de antemão, determine o que é o seu de cada um, o que lhe é devido ou a que tem direito, para terem os demais, ainda segundo essa ordem normativa, deveres correspondentes. Assim, diz ele, "o valor justiça que esta norma constitui identifica-se com o valor ou valores que são constituídos por meio das normas do ordenamento - do ordenamento jurídico em particular - que é pressuposto no momento de sua aplicação". ${ }^{37}$ Esta regra de justiça é, portanto, tautológica e nominal, tanto que, ao tempo de Aristóteles, permitia que se considerasse justa e natural a escravidão, bem como a submissão das mulheres ${ }^{38}$. A transposição das desigualdades naturais para o plano jurídico foi a visão predominante na Antiguidade clássica até, pelo menos, o advento das idéias do estoicismo romano e do cristianismo. ${ }^{39}$

34 A noção de "máxima" aqui utilizada é a que aparece no trabalho de KELSEN sobre a Justiça (nota 6. p. 21), quando, discutindo a Metafisica dos Costumes de Kant, diz ser a "máxima" a regra fundamental segundo a qual o homem deve e quer agir, isto é, um imperativo, uma norma universal. "Com efeito, um homem pode de fato querer de toda e qualquer máxima que ela se transforme numa lei universal."

35 Formulação romana da máxima: a cada um o que é seu.

36 KELSEN. Nota 6, p. 18.

37 KELSEN. Nota 6, p. 18.

38 KELSEN, discutindo as idéias artistotélicas, afirma que Aristóteles “pressupõe evidentemente como injusto aquilo que é injusto segundo a moral e o direito positivos. A autêntica função da teoria do mesotes nāo é determinar a essência da justiça, mas reforçar a vigência do ordenamento social existente, estabelecido pela moral e pelo direito positivos. Aqui, nesta funçāo conservadora, reside sua função política". Nota 6, p. 31.

39 Os estóicos antigos, muito antes de Hobbes e Rousseau formularam a hipótese de um "estado de natureza" anterior ao "estado civil", isto é, de um estado decorrente da comum participaçāo dos homens no logos divino, do qual resulta a sua igualdade essencial. Segundo tal concepçăo, existe um conjunto de princípios éticos que emanam da razão que rege o universo - da natureza - o chamado direito natural universal, antecedente imediato da teoria cristã da lex aeterna e da lex naturalis, formulada mais tardiamente. Cícero, em Roma (106-43 a.c.), influenciado pelo epicureísmo médio, também considera a existência de uma lei natural e de um estado de natureza: "É, pois, a República coisa do povo, considerado tal, não todos os homens de qualquer modo congregados, mas a reunião que tem seu fundamento no consentimento jurídico e na utilidade comum" (República, I, XXV)l ainda, Cícero, sobre a igualdade: “(...) quando o povo sabe, ao contrário, manter suas prerrogativas, nāo é possível a esses encontrar mais glória, prosperidade e liberdade, porque entāo o povo permanece árbitro das leis, dos juízes, da paz, da guerra, dos tratados, da vida e da fortuna de todos e de cada um; então, e só então, é a coisa pública coisa do povo"(...) "Sendo a lei o laço de toda a sociedade civil, e proclamando seu princípio comum a 
A igualdade como "regra de justiça" é, antes de tudo, uma igualdade substancial, isto é, a que postula o tratamento uniforme de todos os homens ou "uma igualdade real e efetiva perante os bens da vida", ${ }^{40}$ que jamais foi plenamente realizada nas sociedades historicamente conhecidas. A igualdade, assim referida, é diferente do posicionamento do homem - de todos e de cada um - face ao poder político, estando imbricada com a justiça geral que, em um conceito amplo, se apresenta como elemento estrutural da mesma e "não se confunde com o conceito estrito ou jurídico, de igual tratamento dos cidadãos pelo poder político". ${ }^{41}$

$\mathrm{O}$ reconhecimento ou a presunção de uma igualdade natural dos homens, com o corolário de tratamento igualitário, chamada de "igualdade constitucional", "mandato da igualdade" ou "técnica da igualdade" foi a novidade fundamental da filosofia racionalista e individualista dos séculos XVII e XVIII, consagrada em todas as Declarações de Direitos do Homem ${ }^{42}$ que se seguiram às Revoluções Liberais, até

igualdade, sobre que base assenta uma associaçāo de cidadāos cujos direitos não são os mesmos para todos? Se não se admite a igualdade de fortuna, se a igualdade da inteligência é um mito, a igualdade dos direitos parece ao menos obrigatória entre os membros de uma mesma república. Que é, pois, o Estado, senão uma sociedade para o direito? (República, II, XXXII).

Para os cristāos, sendo o homem criado à imagem e semelhança de Deus - reflexo do esplendor divino -, por sua alma espiritual e imortal converte-se em "pessoa", em ser dotado de valor próprio, de intrínseca dignidade. O cristianismo revela ao homem sua intimidade, chama-o a meditar sobre a vida do espírito, levando-o a conhecer e a afirmar uma vontade superior e um direito anterior, não sujeito ao arbítrio e paixão dos homens. Essa doutrina - dos escolásticos - forneceu aos indivíduos os elementos psicológios e filosóficos que acabariam por torná-los independentes tanto da autoridade civil quanto da religiosa, em contradição com a visão clássica, que absorvia inteiramente o homem na natureza ou na sociedade. É de se observar, entretanto, que, em seus primórdios, essa concepção postula uma ordem universal unitária em que não há total independência do homem em face do grupo social. A formulação final foi fruto do desenvolvimento que essa doutrina teve nos séculos posteriores, chegando-se, assim, à noção de que além de uma mesma comunidade de origem e natureza a fundamentar sua essencial igualdade, é, sobretudo, a comum filiação divina que faz todos os homens irmãos. Para isso, vez, também: PONTES DE MIRANDA, nota 12, Parte IV, pp. 409/517; BOBBIO, N., nota 12; CURCIO, Carlo, nota 5; PALADIN, Livio. EGVAGLANZA (diritto constitucionale), artigo da Enciclopedia del Diritto, cit.; CASTANHEIRA NEVES, nota 21; FASSÒ, Guido, nota 14; CHÂTELET, François. Historia da Filosofia, Vol. I. De Platäo a São Tomás de Aquino. Publicações Dom Quixote, Lisboa, 1995; PANIÁGUA, José Maria Rodriguez, nota 14; EPICURO/LUCRÉCIO/CÍCERO/SẾNECA e MARCO AURÉLIO, Coleção “Os Pensadores". Abril Cultural, São Paulo, 1980; VILLEY, Michel, nota 18.; TRUYOL Y SERRA, nota 14.

40 BASTOS, Celso Ribeiro. Nota 22, p.

41 FERREIRA PINTO, Maria da Glória. Nota 7., p. 23.

42 Virginia Bill of Rights, de 12.6.1776, Constituiçāo de Massachussets, de 2.3.1780, Declaração dos Direitos do Homem de 1789, art. 12, "les hommes naissent et demeurent libres et éguax en droits. Les distinctions sociales ne peuvent être fondées que sur l'utilité commune" (os homens nascem e permanecem livres e iguais em direitos. As distinções sociais só podem ser fundadas na utilidade comum) e Declaraçāo Universal dos Direitos Humanos de 1948, art. 10; "Todos os seres humanos nascem livres e iguais em sua dignidade e direitos, dotados como sāo de razāo e consciência, devem comportar-se fraternalmente uns com os outros"; art. 20: "Toda pessoa tem todos os direitos e liberdades proclamados nesta Declaração, sem distinção alguma de raça, cor, sexo, idioma, religião, opinião política ou de qualquer outra índole, origem nacional ou social, posiçāo econômica, nascimento ou qualquer outra condição" (Todos los seres humanos nacen libres e iguales en su dignidad y derechos e, dotados como están de razón y conciencia, debem comportarse fraternalmente los unos con los otros; Toda persona tiene todos los derechos y libertades proclamados en esta Declaración, sin distinción alguna de raza, color, sexo, idioma, religión, 
se converter um dogma jurídico-político nos Estados Modernos. O conteúdo desse princípio, seu alcance e significado histórico é o que passaremos a tratar mais de perto.

\section{O mandamento constitucional da Igualdade}

A partir da consideração de um hipotético estado de natureza, feita inicialmente por Hobbes, no séc. XVII, e seguido por Locke, postulou-se serem todos os homens livres e iguais na natureza e desigualando-se apenas quando passam para o "estado civil", para o fim de obter paz, segurança e conservar a liberdade e propriedade. ${ }^{43}$

opinión política o de cualquier otra índole, origen nacional o social, posición econômica, nacimiento o cualquier otra condición). Os textos se encontram em CLAVERO B., nota 12, p. 223 e ROBERT, Jacques \& OBERDORFF. Libertés fundamentares et droits de l'homme. Montchrestien, Paris, 1995, p. 167.

43 "A natureza fez os homens tão iguais, quanto às faculdades do corpo e do espírito, que, embora por vezes se encontre um homem manifestamente mais forte de corpo, ou de espírito mais vivo que outro, mesmo assim, quando se considera tudo isto em conjunto, a diferença entre um e outro homem não é suficientemente considerável para que qualquer um possa com base nela reclamar qualquer benefício a que outro nāo possa também aspirar, tal como ele" (Leviatã, Cap. XII, ediçāo "Os Pensadores". Abril Cultural, São Paulo, 1979, p. 74); (...) “durante o tempo em que os homens vivem sem um poder comum capaz de manter a todos em respeito, eles se encontram naquela condição a que se chama guerra; $e$ uma guerra que é de todos os homens contra todos os homens" (ob. cit., p. 75); (...) "que um homem concorde, quando os outros também o façam, e na medida em que tal considere necessário para a paz e para a defesa de si mesmo, em renunciar a seu direito a todas as coisas, contentando-se, em relação a outros homens, com a mesma liberdade que aos outros homens permite em relação a si mesmo" (ob. cit., Cap. XIV, p. 79); (...) "Daquela lei da natureza pela qual somos obrigados a transferir aos outros direitos que, ao serem conservados, impedem a paz da humanidade, segue-se uma terceira: Que os homens cumpram os pactos que celebrarem. Sem essa lei os pactos seriam vãos, e nāo passariam de palavras vazias, como o direito de todos os homens a todas as coisas continuaria em vigor, permaneceriamos na condição de guerra" (ob. cit., Cap. XV, p. 86).

Ver também BONAVIDES, Paulo. Política e Constituifãa, Os Caminhos da Democracia. Forense, Rio de Janeiro, 1985, pp. 293/316 e LOCKE, John. Segundo Tratado Sobre o Governo. Coleçåo "Os Pensadores", Abril Cultural, São Paulo, 1979. "Para bem compreeender o poder político e derivá-lo de sua origem, devemos considerar em que estado todos os homens se acham naturalmente, sendo este um estado de perfeita liberdade para ordenar-lhes as açōes e regular-lhes as posses e as pessoas conforme acharem conveniente, dentro dos limites da natureza, sem pedir permissäo ou depender da vontade de qualquer outro homem" (ob. cit., p. 35); (...) Estado também de igualdade, no qual é recíproco qualquer poder e jurisdição, ninguém tendo mais do que qualquer outro; nada havendo de mais evidente que criaturas da mesma espécie e da mesma ordem, nascidas promiscuamente a todas as mesmas vantagens da natureza e ao uso das mesmas faculdades, terāo também de ser iguais umas às outras sem subordinação ou sujeição;" (ob. cit. idem); (...) "Se um homem no estado de natureza é tão livre, conforme dissemos, se é senhor absoluto de sua própria pessoa e posses, igual ao maior e a ninguém sujeito, por que abrirá ele māo dessa liberdade, por que abandonará o seu império e sujeitar-se-á ao que domínio e controle de qualquer outro poder? Ao que é óbvio responder que, embora no estado de natureza tenha tal direito, a fruição do mesmo é muito incerta e está constantemente exposta à invasão de terceiros, porque, sendo todos reis tanto quanto ele, todo homem igual a ele, e na maior parte pouco observadores da equiidade e da justiça, a fruição da propriedade que possui neste estado é muito insegura, muito arriscada. Estas circunstâncias obrigam-no a abandonar uma condiçāo que, embora livre, está cheia de temores e perigos constantes; e não é sem razāo que procura de boa vontade juntar-se em sociedade com outros que estão 
Foi Rousseau, todavia, seguindo as concepções aristotélicas (igualdade nas relações), ${ }^{44}$ quem teorizou a igualdade civil, considerando a existência de dois tipos de desigualdades: as naturais ou fiscais e as morais ou políticas, ${ }^{45}$ sendo que as políticas - estabelecidas por lei - tinham como fundamento a propriedade privada: "o verdadeiro fundador da sociedade civil foi o primeiro que, tendo cercado um terreno, lembrou-se de dizer isto é meu, e encontrou pessoas suficientemente simples para acreditá-lo" ${ }^{46}$ mas que, ainda assim e por isso mesmo, todos os homens deveriam ser considerados iguais perante a lei (devant la loi), para que não reinasse o despotismo político a partir da diferença de posses, que em última instância, era a principal causa das desigualdades.

Kant, já no séc. XVIII, articula igualdade à liberdade, com centro ou cerne da própria noção de Direito, asseverando ser o direito o conjunto das condições por meio das quais a vontade de um pode estar de acordo com a de outro, segundo uma lei geral de liberdade limitada pelo critério da igualdade, que só pode ser garantida por uma "legislação pública" existente no "estado civil", constituído através de um contrato (pacto de submissão) entre vontades livres. No estado civil, a lei, obrigatória para todos, assegura essa liberdade determinada segundo leis gerais, ou a igualdade na liberdade.

" a liberdade (independência do arbítrio de outro) na medida em que possa subsistir com a liberdade de todos, segundo uma lei universal, é esse direito único, primitivo, próprio de cada homem, pelo simples fato de ser homem". ${ }^{47}$

A igualdade natural, é, por sua vez, "impossibilidade moral de ser obrigado

já unidos, ou pretendem unir-se, para a mútua conservação da vida, da liberdade e dos bens a que chamo de "propriedade". (ob. cit., p. 82).

44 Ver ARISTÓTELES, Política, Ediouro, Coleçāo Clássicos de Bolso, Rio de Janeiro, s/d. Por exemplo, no Livro Sétimo, Capítulo I, parágrafo 6\%, assevera o estagirita: “ $O$ princípio fundamental do governo democrático é a liberdade; a liberdade, diz-se, é o objeto de toda democracia. Ora, um dos característicos essenciais das liberdade é que os cidadāos obedeçam e mantêm alternativamente; porque o direito ou a justiça, em um Estado popular, consiste em observar a igualdade em relaçāo ao número, e não a que se regula pelo mérito. Segundo essa idéia do justo, é preciso forçosamente que a soberania resida na massa do povo, e que aquilo que ele tenha decretado seja firmado como o direito ou justo por excelência, pois que se pretende que todos os cidadãos têm direitos iguais. Disso resulta que, nas democracias, os pobres têm mais autoridade que os ricos, pois que são em maioria, e os seus decretos têm força de lei. Eis aí, pois, um sinal característico das liberdades tal é a definição que todos os partidários do Estado popular dão da república", p. 136/137.

45 "Concebo, na espécie humana, dois tipos de desigualdade: uma que chamo natural ou física, por ser estabelecida pela natureza e que consiste na diferença das idades, da saúde, das formas do corpo e das qualidades do espírito e da alma; a outra, que se pode chamar de desigualdade moral ou política, porque depende de uma espécie de convençāo e que é estabelecida ou, pelo menos autorizada pelo consentimento dos homens" (Discurso sobre a origem e os fundamentos da desigualdades entre os Homens. "Os Pensadores", São Paulo, 1979, pág, 234).

46 Nota 45, p. 259 e ss. e p. 265 : “"mas, desde o instante em que um homem sentiu necessidade do socorro de outro, desde que se percebeu ser útil a um só contar com provisōes para dois, desapareceu a igualdade, introduziu-se a propriedade, o trabalho tornou-se necessário e as vastas florestas transformaram-se em campos aprazíveis que se impôs regar com o suor dos homens e nos quais logo se viu a escravidāo e a miséria germinarem e crescerem com as colheitas".

47 KANT, Emmanuel. Doutrina do Direito. Ícone Editora, São Paulo, 1993, p. 55. 
pelos demais a mais coisas do que aquelas a que estão obrigados com respeito a nós", ${ }^{48}$ e, no estado civil ou societas civilis

"a liberdade legal de não obedecer a nenhuma outra lei, além daquelas que tenham dado seu sufrágio (...), a igualdade civil, que tem por objeto não reconhecer entre o povo nenhum superior além daquele que tem a faculdade moral de obrigar juridicamente da mesma maneira que, por sua vez, pode ser obrigado"

são atributos jurídicos inseparáveis da natureza do cidadão (os membros reunidos do estado civil, isto é, uma cidade para a legislação). ${ }^{49}$

\section{A. A Igualdade Formal}

Não só na liberdade os homens são iguais, mas também na razão, que é o centro do pensamento iluminista do séc. XVIII, porque permite, em termos jurídicos, a construção de um "sistema" (de princípio dados, inquestionáveis, apreensíveis da natureza, dos quais se deduzem todas as soluções, para os casos concretos) que ordena toda a vida social. Tais idéias foram a base filosófica e doutrinária das Revoluções Liberais, que concederam o homem como indivíduo contrapesto ao Estado de modo abstrato, fora de todas as sociedades particulares ${ }^{50}$ e foram a consequiência histórica do surgimento de uma esfera distinta da do Estado, considerada como privada, composta, basicamente, de interesses econômicos. Contra a ordem estatal, se instituiu a sociedade civil ou burguesa (terminologia hegeliana), embora, nos filósofos acima analisados, o Estado mesmo tenha sido considerado como "sociedade civil", contraposto ao estado de natureza. Daí decorre o dogma da prevalência da lei como fonte de direito, exprimindo uma concepção específica deste último, como ordenamento racional da sociedade. Tal ordenamento não pode nascer de comandos individuais e ocasionais, mas somente de normas gerais e coerentes postas pelo poder soberano da sociedade. Dar prevalência à lei como fonte do direito nasce do propósito revolucionário de mudar a sociedade e de romper com a tradição jurídica. ${ }^{\text {si }} \mathrm{O}$ projeto Iluminista de racionalização integral da sociedade $\mathbf{e}$ do Estado postulou o governo das leis (da razão) e não dos homens, em função da garantia dos Direitos Fundamentais, por reconhecer uma esfera "privada" inviolável e inatingível pela ação estatal. Embora existisse, na Antiguidade, a noção de que a generalidade das leis era a garantia contra a tirania do governo dos homens, de

48 KANT. Nota 47, p. 55.

49 KANT. Nota 47, p. 153.

so TOCQUEVILLE, Alexis, in: $O$ Antigo Regime e a Revolução. Coloģăo "Os Pensadores", Abril Cultural, 1979, São Paulo, pp. 327 e ss. asseverou que a Revolução Francesa foi uma revoluçio política que tomou o aspecto de uma revolução religiosa, porquanto penetrou pela pregação e propaganda e porque considerou o homem do mesmo modo que as religiōes o consideram em geral, "independentemente do país e do tempo".

51 Para estas consideraçōes, ver HABERMAS, Jurgen. Mudança Estrutural da Esfera Püblica. Tempo Brasileiro, Rio de Janeiro, 1984; MENEZES CORDEIRO, Antonio. Introdução a Pensamento Sistemático e Conceito de Sistema na Ciência do Direito, de Canaris, cf. nota 17; BOBBIO, Estado, Governo e Sociedade, Paz e Terra, São Paulo, 1992; O Positivismo Jurídico - Lị̧ōes de Filosofia do Direito, nota 13; HELLER, Herman, Teoria del Estado, Fondo de Cultura Econômica, México, 1955. 
medida individual, não havia, entretanto, uma clara consciência entre uma verdadeira oposição indivíduo/Estado, que só foi possível com a reflexão jusnaturalista e as idéias cristãs.

A Revolução Francesa, portanto, consolidou um longo esforço de "jurisdicização" do poder estatal e de "domesticação" da Administração ${ }^{52}$ e o Estado limitado juridicamente aparece indissociavelmente ligado à luta da burguesia contra o Estado de Polícia e contra as barreiras sociais da sociedade estamental e passou a ser entendido como "o que estabelece relaçōes entre uma comunidade dotada de um poder de autoridade e as pessoas que lhe são iguais ou lhe estão subordinadas". ${ }^{53} \mathrm{~A}$ limitação do poder do Estado se fez, essencialmente, através de técnicas de natureza jurídica, tais como a divisão de poderes - estabelecimento de um conjunto de órgãos para exercer distintas funções, sendo que pelo menos um deles, o legislativo, deriva de eleição, com competências pré-determinadas pela Constituição - , a consagração da supremacia do Poder Legislativo, através da idéia de "império da lei" e subordinação do Executivo garantida pelo Princípio da Legalidade. $O$ objetivo final, de garantir a liberdade e os Direitos Fundamentais, traduziu-se, assim, no estabelecimento de um sistema de garantias, de natureza jurídica, impregnando toda a estruturação do Estado e enquadrando as suas relações com a sociedade. Estas técnicas jurídicas, de caráter instrumental, acabaram por se afirmar como verdadeiros e autônomos valores.

O Estado limitado juridicamente ou "Estado de Direito" ${ }^{54}$ combina as formulações que encerram os dois princípios fundamentais regentes das relações entre Estado e cidadão: o da Legalidade e o da Igualdade. Através do "Estado de Direito", reivindica-se um direito igual para todos, válido universalmente, pois é a regulamentação abstrata, geral e anterior que garante a igualdade perante a lei (jurídica), bem como a vinculação das autoridades políticas e dos cidadãos pela lei e atos que lhe são assimiláveis. Com a generalidade da lei, ficam asseguradas a certeza, previsivilidade, racionalidade e justiça das limitações na esfera da liberdade e propriedade

52 A expressão é de Jorge Reis NOVAIS. Contributo para uma Teoria do Estado de Direito, Coimbra, 1987, pp. 26/37.

53 JELLINECK, Georg. Compedido de la Teoria General del Estado, Editor Manuel de I. Mucamendi, México, 1936, p. 148.

54 Essa construção - Rechsstaat - formulada pelos teóricos alemães e guardando semelhanças com as idéias de "Estado Constitucional" francês e norte-americano e do "rule of law" britânico, não moldou constitucionalmente o Estado em função das garantias dos Direitos Fundamentais e sim "o perspectivou em torno de sua dimensão técnico-formal" (NOVAIS, Jorge Reis, nota 52, p. 39/40), a partir da construção do Princípio da Legalidade e da Justiça Administrativa, intuindo a importância das regras jurídicas no processo de limitaçāo do Estado. No Estado Constitucional de tipo francês, a tônica foi colocada nos mecanismos políticos, como o controle parlamentar e as garantias constitucionais. Das duas teorias resultou à concepçāo de que a Constituiçāo - tida como direito político por excelência - se impōe globalmente a todas as funçōes estatais, por ser o fruto da "vontade geral soberana".

KELSEN, na Teoria Pura do Direito, nota 11, pp. 383/390, critica esta construção "Estado de Direito", argumentando que todo Estado é de "Direito", na medida em que é uma ordem jurídica relativamente centralizada e que "para ser um Estado, a ordem jurídica necessita ter o caráter de uma organização no sentido estrito da palavra, quer dizer, tem de instituir órgāos funcionando segundo o princípio da divisão do trabalho para a criação e aplicação das normas que a formam". 
de cada um, e as relações sociais, desse modo, podem aperfeiçoar-se..$^{55}$ Estado de Direito é, por essas razões, aquele em que estão garantidos os Direitos Fundamentais e a divisão de poderes (império da lei e princípio da legalidade) e sua adjetivação de liberal, feita na século passado, advém da concretização particular que as técnicas de limitação assumem em um contexto em que os Direitos Fundamentais são condicionados pelos valores burgueses". ${ }^{56}$

A Igualdade de todos - todos os homens são (ou nascem) iguais - veio, então; referida como igualdade absoluta, sem reservas, trazendo implícita a idéia de um tratamento pela lei em termos absolutos, independentemente do conteúdo desse tratamento, pois, ainda que se reconheçam as desigualdades existentes entre os homens, considera-se serem as mesmas irrelevantes no âmbito do tratamento jurídico. O princípio da igualdade aparece, assim, sem qualquer graduação, traduzido em mero princípio de prevalência da lei, isto é, em um dado puramente formal; "A igualização de todos numa classe única, a dos cidadãos, é o objetivo que se pretende atingir através da generalidade da lei, que deste modo se apresenta como exigência última do princípio da igualdade". ${ }^{57}$ Desta forma, o critério que iguala os homens é o momento de aplicação da lei, que vale para todos indistintamente e é aplicada uniformemente. Ser considerado igual perante uma determinada lei é ser o destinatário de sua aplicação. A observância da devida igualdade dirige-se ao aplicador da lei - juiz ou a Administração - que estão proibidos de estabelecer distinções onde a lei não se estabelece.

Convém não esquecer que, historicamente, o alvo principal da afirmação contida no art. $1^{2}$ da Declaração de 1789 ('os homens nascem e permanecem livres e iguais em direitos. As distinções sociais só podem ser fundadas na utilidade comum") foi o Estado estamental, cujos cidadãos estão divididos em superiores e inferiores, a cada um se aplicando um ordenamento jurídico diferenciado, restando implícita a proibição de se eleger como critério diferenciador o nascimento, "critério sobre o qual se fundam as aristocracias". ${ }^{58}$ Subjaz a esta concepção a convicção de que só a generalidade da lei permitia a extinção dos privilégios e sujeições da sociedade estamental, em um esquecimento da dimensão relativa da igualdade, "baseada na fungibilidade dos homens, igualados na razão"..$^{9}$ Isto não quer dizer que outros critérios de discriminação de tratamento não fossem mantidos pelo legislador, tais como as posses e o sexo, de que a proibição do voto dos trabalhadores e das mulheres, no caso de participação na vida do Estado, é um exemplo. "Todos", neste caso, eram nobres, burgueses proprietários e pequeno burgueses (artesãos, comerciantes, profissionais liberais) e jamais proletários, cuja única propriedade é a força de trabalho, vendido como mercadoria, ou mulheres, equiparadas às crianças e, portanto, "menores" civis.

55 Ver FLEINER, Fritz. Principes Généraux du Droit Administratif Allemand. Librarie Delagrave, Paris, 1933, p. $92 / 93$.

56 NOVAIS, Jorge. Nota 52, p. 70.

57 FERREIRA PINTO, Maria da Glória. Nota 7, p. 26.

58 BOBBIO. Nota 2, p. 28.

59 FERREIRA PINTO, Maria da Gloria. Nota 7, p. 29. 
O mandato de igualdade, nos termos postos pela filosofia liberal, dirigia-se tão-somente ao juiz e à Administração: o legislador restava livre para qualificar como "igual" ou "desigual" as mais diversas situações e, partindo-se de uma abstração que unificava o sujeito destinatário das normas, a lei, ao fim e ao cabo, serviu para perpetrar e cristalizar as desigualdades substanciais existentes entre os homens. A igualdade "seria, afinal, desigualdade", como notou Castanheira Neves ${ }^{\text {(10 }}$ e o direito, um instrumento de dominação, conforme a crítica arrasadora de Marx, na Crítica ao Programa de Gotha."

Para Marx, a igualdade "burguesa" é um termo médio e proporcional ao trabalho prestado, mas este não pode servir de medida porque alguns indivíduos trabalham mais, e outros menos, além do que, para servir de medida, o trabalho "tem de ser determinado quanto à duração ou intensidade". ${ }^{62}$ Assim, o "direito igual" é um direito desigual para trabalho desigual para trabalho desigual e se este não reconhece nenhuma distinção de classe, mas reconhece tacitamente as desiguais aptidões dos indivíduos e a desigual capacidade de rendimento, "no fundo, é, portanto, como todo direito, o direito da desigualdade" ${ }^{63}$ A lei, para Marx, não reflete a vontade geral soberana e sim a vontade da classe burguesa. Nestas condições, a igualdade nada significa, é só um dado formal. Para existir verdadeiramente igualdade, é necessário que esta seja material, substancial, o que só surgirá com o desaparecimento das classes artificialmente estratificadas, ou com a Revolução Socialista.

" $O$ direito só pode consistir, por natureza, na aplicação de uma medida igual; mas os indivíduos desiguais (e não seriam um individuos diferentes se não fossem desiguais) só podem ser medidos por ma mesma medida sempre e quando sejam considerados sob um ponto de vista igual, sempre e quando sejam olhados sob um aspecto determinado; por exemplo, no caso concreto, só como operários, e não se veja neles nenhuma outra coisa, isto é, prescinda-se de tudo o mais. Prossigamos: uns operários são casados e outros não, uns têm mais filhos que outros etc. etc. Para igual trabalho e, por conseguinte, para igual participação no fundo social de consumo, uns obtêm de fato mais do que outros, uns são mais ricos do que outros etc. Para evitar todos estes inconvenientes, o direito não teria que ser igual, mas desigual". .4

A crítica marxista se insere em um quadro de profundas transformaçōes da sociedade e do Estado, na Europa do séc. XIX, palco de intensas lutas sociais, decorrentes, basicamente, do extremo estado de penúria das classes trabalhadoras e de sua conseqüente organização política. A feição do Estado, antes "liberal", onde os direitos fundamentais de liberdade pessoal, política e econômica constituíam um

60 Nota 20, p. 231.

61 A tradução aqui utilizada é a que consta, in: Obras Escolhidas, Karl Marx e Friedrich Engels. Vol.

2. Editora Alfa-Omega, Sāo Paulo, s/d., pp. 203 a 234.

62 Nota 60 , p. 214.

63 O destaque está no texto. Nota 60 , p. 214.

64 Nota 60, p. 214. 
limite à intervenção estatal, mudou para sempre: surgem os direitos sociais como consequiência direta das lutas dos trabalhadores, representando direitos de participação no poder político e na distribuição da riqueza social. A gradual integração do Estado com a sociedade civil acabou por alterar a sua forma jurídica, os processos de legitimação e a estrutura da Administração.

Com o desenvolvimento capitalista e adoção de novas tecnologias, associado à concentração de mão-de-obra nos centros urbanos, ao ascenso das classes trabalhadoras e ao aparecimento das doutrinas socialistas e da doutrina social cristã (de larga repercussão histórica), combinado com a universalização do sufrágio e organização de partidos políticos, além do crescente intervencionismo estatal nas relações privadas, surge uma nova forma de Estado, o chamado Estado Social. O pluralismo democrático, a redefinição do papel dos parlamentos e a adoção da fidelidade partidária, bem como a adoção de novos direitos fundamentais que, ao lado das liberdades públicas, asseguraram um quadro de valores mínimos a serem perseguidos (bem-estar social e distribuição mais equiitativa da riqueza), são as principais características desta nova forma estatal. ${ }^{65} \mathrm{~A}$ tutela fundamental não é mais a propriedade privada e sim a dignidade da pessoa humana como centro invariável da esfera da autonomia individual que se procura garantir através da limitação jurídica do Estado. Exige-se agora do Estado uma intervenção positiva, para criar as condições de uma real vivência e desenvolvimento da liberdade e personalidade individuais. No Estado Social de Direito, cuida-se de articular direitos, liberdades e garantias (proteção da autonomia da pessoa) com os direitos sociais (refazer as condições materiais);

"de articular igualdade juridica (à partida) com igualdade social (à chegada) e segurança jurídica com segurança social (...) Embora com projeção no plano do sistema político (com passagem do governo representativo clássico à democracia representativa), é no âmbito dos direitos fundamentais e no da organização econômica que mais avulta o Estado social de Direito". ${ }^{66}$

\section{A Igualdade de Chances}

A igualdade, então, foi pensada em termos de igualdade de chances ou de oportunidades, ou, ainda, de pontos de partida, a partir da consideração de que "toda a vida social é considerada como uma grande competição para a obtenção de bens escassos" ${ }^{67}$ Com o objetivo de colocar todos os membros da sociedade em condições iguais de competição pelos bens da vida considerados essenciais, muitas vezes é necessário favorecer uns em detrimento de outros. Introduzem-se, assim, artificialmente, ou imperativamente, discriminações que de outro modo não existiriam: "uma desigualdade torna-se um instrumento de igualdade pelo simples motivo de que

65 Sobre o Estado Social ou Welfare State, ver. SALDANHA JÚNIOR. Cézar Souza. $O$ consensus no Constitucionalismo Ocidental. Tese de Doutorado em Direito Constitucional, USP, 1984; HABERMAS, Jurgen, nota 49; JORGE MIRANDA, nota 1; CANOTILHO, J. J. Gomes, nota 12; NOVAIS, Jorge Reis, nota 52; FLEINER, F., nota 55; JELLINECK, nota 53; HELLER, H. nota 51.

66 MIRANDA, Jorge. Nota 1. Tomo I, p. 95.

67 BOBBIO. Nota 2, p. 31. 
corrige uma desigualdade anterior: a nova igualdade é o resultado da equiparação de duas desigualdades". ${ }^{88}$ Assim foi com o surgimento do Direito do Trabalho, pois a inferioridade econômica do trabalhador — uma desigualdade — foi corrigida com uma desigualdade em sentido oposto ou compensatória: o Estado colocou a favor deste o peso da lei. "Mais tarde, a desigualdade compensatória foi obtida por via mais adequada - no sentido de mais sua e mais apropriada - criando a força que resulta da união". ${ }^{69}$

O filósofo inglês John Rawls, ${ }^{70}$ posteriormente, ao formular uma das mais influentes teorias contemporâneas sobre a Justiça, aduziu que esta é eqüidade e igualdade de oportunidades, possuindo dois princípios gerais: o primeiro, que

"toda pessoa tem o mesmo direito a um esquema plenamente válido de iguais liberdades básicas que sejam compativeis com um esquema similar de liberdades para todos"; e o segundo, de que "as desigualdades sociais e econômicas devem satisfazer a duas condições. Em primeiro lugar, devem estar associadas a cargos $e$ posições abertos a todos em igualdade de oportunidades; em segundo lugar, devem supor o maior beneficio para os membros menos avantajados da sociedade"."

Em outras palavras, exige-se igualdade na repartição de direitos e deveres básicos, e mantém-se as desigualdades sociais e econômicas, como por exemplo, de riqueza e de autoridade, se são justas, isto é, se produzem benefícios compensadores para todos. Esta concepção é próxima daquela que baseia a igualdade na repartição dos bens produzidos - a utilitarista —, mas com ela não se confunde, segundo a critica que o próprio autor lhe faz, porque "o utilitarismo não considera seriamente a distinção entre pessoas". ${ }^{72}$

Foi exatamente o surgimento dos grupos intermediários entre o indivíduo e o Estado - sindicatos, partidos políticos, associações —, no séc. XIX, que possibilitou

68 BOBBIO. Nota 2, p. 32.

69 RODRIGUEZ, Américo Plá. Princípios de Direito do Trabalho. Ed. LTR, São Paulo, 1993, p. 25.

70 In: Teoria de la Justicia, Fondo de Cultura Econômica, México, 1993; Las libertades fundamentales y su prioridad, in: Libertad. Igualdad Y Derecho - Las conferencias Tanner sobre filosofia moral (John RAWLS, Charles FRIED, Amartya SEN y Thomas C. SCHELLING), Editorial Ariel, Barcelona, 1988; ver, ainda, DWORKIN, Ronald. Ética privada e igualitarismo político, Ediciones Paidós, I.C.E. de la Universidad Autónoma de Barcelona, Barcelona, 1993.

71 Las libertades fundamentales y su prioridad, nota 70, p. 13, verbis: “1. Toda persona tiene el mismo derecho a un esquema plenamente válido de iguales libertades básicas que sea compatible con un esquema similar de libertades para todos, 2. Las desigualdades sociales y económicas deben satisfacer dos condiciones. En primer lugar, deben estar associadas a cargos y posiciones abiertos a todos en igualdad de oportunidades; en segundo lugar, deben suponer el mayor beneficio para los miembros menos avantajados de la sociedad"; Teoria de la Justicia, nota 70, p. 82, verbis: "Primero: Cada persona ha de tener un derecho igual al esquema más extenso de libertades básicas iguales que sea compatible con un esquema semejante de libertades pra los demás. Segundo: Las desigualdades sociales y económicas habrian de ser conformadas de modo tal que a la vez que: a) se espere razonablemente que sean vantajosas para todos, b) que se vinculem a empleos y cargos asequibles para todos".

72 Teoria de la Justicia, nota 70, p. 46. Rawls indica ser a idéia principal do utilitarismo clássico aquela segundo a qual está corretamente ordenada e é justa a sociedade em que as instituiçōes mais importantes estão estruturadas de modo a obter o maior nível de satisfação distribuído entre todos os seus membros. 
o reconhecimento definitivo de "que as condições singulares dos indivíduos, independentemente da razão que a todos une, exigem tratamento diversos, sob pena de se criarem ou potenciarem diferenças sociais não menos injustas do que as de épocas passadas". ${ }^{73}$

\section{A Igualdade "na" lei}

No âmbito político, retorna-se, então, à concepção da igualdade relativa, e a máxima "todos são iguais perante a lei" passa a ser entendida como a composição de duas afirmações distintas, a saber: o igual deve ser tratado igualmente e o desigual, desigualmente, na medida exata de sua diferença. A desigualdade passa a ser entendida com a "contra-regra" 74 ou regra negativa, porque expressamente admitida. Como assevera Kelsen, o tratamento dos homens sem levar-se em conta nenhuma das desigualdades de fato existentes, "conduz a consequiências absurdas" e por isso mesmo, "não é possível deixar de lado todas as desigualdades em toda e qualquer espécie de tratamento. Certas desigualdades têm de ser tomadas em consideração" ${ }^{75}$ Desta forma, o legislador, por exemplo, só pode estabelecer a obrigatoriedade do serviço militar para adultos ou penas para delinqüentes, sob pena de ditar normas não funcionais (serviço militar para as crianças) e disparatadas (penas para todos). "A igualdade de todos com respeito a todas as posições jurídicas conduziria não só a normas não funcionais, disparatadas e injustas, senão também eliminaria os pressupostos para o exercício de competências". ${ }^{76} \mathrm{O}$ Princípio da Igualdade, assim concebido, perde um pouco de seu significado e conteúdo próprios, para se confundir com o princípio da legalidade: aplicar fielmente ou corretamente a lei, ${ }^{n}$ reforçando a vinculação dos órgãos aplicadores do direito às normas editadas pelo legislador, sem que se estabeleçam quaisquer exigências no que tange ao conteúdo destas normas, isto é, sem vincular o legislador. Normalmente, é a lei que discrimina, as situações, para submetê-las à regência de tais ou quais regras, e o problema da igualdade consistirá em saber-se quais discriminações são juridicamente toleráveis, uma vez que a obrigatoriedade de aplicação uniforme da lei a todos por ela abrangidos é apenas a consequiência lógica da aplicação "correta" da lei ${ }^{78}$ ou "a consequiência

73 PINTO FERREIRA, Maria da Glória. Nota 7, p. 29.

74 A expressão é de FROSINI, V. Paradosso dell'eguaglianza. Revista Internazionale di Filosofia del Diritto, IV serie, LIII, Giufré, Milāo, 1976, p. 545.

75 Nota 6, p. 53. Neste capítulo, Kelsen desdobra as idéias já contidas na Teoria Pura, nota 11, p. 203 , no sentido de que "não há nenhum sistema de moral que contenha a norma que manda tratar os menores da mesma forma que os adultos, os homens da mesma forma que as mulheres, os doentes mentais como as pessoas normais, os desordeiros da mesma forma que os pacíficos".

76 ALEXY, R. Nota 3, pág. 384 ("La igualdad de todos con respecto a todas las posiciones, jurídicas conduciria no sólo a normas no funcionales, disparatadas e injustas, sino que también eliminaría los presupuestos para el ejercicio de competencias"); KELSEN. Nota II, p. 203 e ss.

77 Cf. BASTOS, Celso Ribeiro. Nota 22, p. 167.

78 Ver KELSEN, nota 6, pp. 51/62 e nota 11,p. 203; BANDEIRA DE MELLO, Celso Antônio. Conteúdo Juridico do Principio da Igualdade, $3^{2}$ edição, Malheiros Editores, Sāo Paulo, 1993. ALEXY, R. Nota 3, pp. 381/415; FROSINI, Vittorio. Paradosso dell'eguaglianza. Rivista Internazionale di Filosofia del Diritto, IV serie, LII, Giufré, Milão, ottobre-dicembre, 1976, pp. 540/547. 
lógica do caráter geral da norma que prescreve que, verificado um determinado pressuposto, se deve produzir determinada consequiência". ${ }^{79}$

Daí decorre que a chamada "igualdade perante a lei" é a aplicação correta da lei qualquer que seja o seu conteúdo, isto é, ainda que ela não prescreva um tratamento igualitário mas um tratamento desigual. Esta igualdade será, portanto, "conformidade com a norma" 80 e difere, segundo numerosos jurista, da "igualdade na lei" ou igualdade na formulação do direito, concebida como igualdade material ou que vincula também o legislador.

O mandato da igualdade só vincula concretamente o legislador se a fórmula "há que se tratar igualmente aos iguais e desigualmente os desiguais" é interpretada como uma exigência de conteúdo, ou um mandato de igualdade material, obrigando o legislador à criação de um direito igual para todos. O princípio da igualdade na lei, torna-se, assim, um postulado de racionalidade prática: "para todos os indivíduos com as mesmas características devem prever-se, através da lei, iguais situações ou resultados jurídicos". ${ }^{81}$ No entanto, este postulado não diz muito, uma vez que o legislador poderia fazer qualquer discriminação sem estar, necessariamente, violando-o. Por essa razão, o Tribunal Constitucional Federal da Alemanha, por exemplo, já em suas primeiras decisões, considerou ser evidente a vinculação do legislador ao princípio da igualdade - igualdade na formulação do direito - tratando de conduzir a questão da igualdade material à da "valoração correta", isto é, a de saber-se o que é uma legislação correta, razoável ou justa, ${ }^{82}$ com a ajuda do conceito de arbitrariedade, agregando ao postulado a expressão "essencial", de modo que o legislador está proibido de tratar: a) o igual desigualmente; b) o essencialmente igual desigualmente e c) o essencialmente igual arbitrariamente desigual, além de, evidentemente, estar proibido, pela própria Constituição, (art. 32, alínea 1 e 3 da Lei Fundamental de Bonn) de fazer distinções com base no sexo, origem, raça, língua pátria e procedência, crença, concep̧̧ões religiosas ou políticas ${ }^{83}$. Assim também o Tribunal Constitucional Português reconduz o problema do critério de valoração para a relação de igualdade à proibição geral do arbítrio: "existe observância da igualdade quando os indivíduos ou situações iguais não são arbitrariamente (proibif̧ão de arbítrio) tratados como desiguais". ${ }^{84}$

79 KELSEN. Nota 6, p. 57.

80 KELSEN. Nota 6, p. 60.

81 CANOTILHO, J. J. Gomes. Nota 12, p. 563; ALEXY, nota 3, p. 386.

82 ALEXY. Nota 3, p. 388

83 Ver, nesse passo, HECK, Luís Afonso. O Tribunal Constitucional Federal e o Desenvolvimento dos Princípios Constitucionais. Sérgio Antonio Fabris Editor, Porto Alegre, 1995, p. 226 e ss (“A proibiçāo de arbitrariedade está compreendida no Princípio do Estado de Direito, configurando-se como um preceito estatal-jurídico geral. Esse limite significa que na seleçāo de situaçōes, que serão reguladas, deve-se proceder de forma apropriada, i.e., segundo pontos de vista que resultem de peculiaridade dos fatos a serem regulados, portanto, não de modo arbitrário. Ela interdita tratamento desigual arbitrário de fatos iguais no essencial"); ALEXY, nota 3, p. 390 e ss.

84 CANOTILHO. Nota 12, p. 565. 


\section{A. O legislador como destinatário}

A discussão sobre o destinatário do princípio da igualdade, que tanto divide os doutrinadores estrangeiros e ainda divide os entendimentos, surpreendentemente, não se estabeleceu no Brasil, pois a doutrina sempre concebeu ser o legislador também destinatário do princípio, a par de aceitar a idéia de que a lei é o critério de distinção que engloba as desigualdades aceitáveis ou não, embora, claramente, só o texto da Carta Magna de 1824 tenha cogitado acerca do conteúdo interno da legislação. ${ }^{85}$ Os demais textos, pelo menos até 1988 , apenas repetiram a formulação da igualdade perante a lei, sendo que, em alguns - $1934^{86}$ e 1946 - agregaram-se, em outros dispositivos, normas que objetivavam materializar critérios de justiça. Mas a hermenêutica dos textos, feita pelos juristas, sempre se direcionou no sentido de que tanto o legislador quanto o executor da lei estavam vinculados ao princípio da igualdade. Proibia-se ao legislador fazer distinções arbitrárias e prescrevia-se que já se ativesse a critérios materiais quando elaborasse as normas. Francisco Campos, ${ }^{87}$ em célebre parecer, foi o primeiro a tratar do tema, sustentando ser o legislador o destinatário principal do princípio da igualdade, pois, do contrário, a ele "ficaria devassada a imensidade de um arbítrio sem fronteiras (...). O carácter de norma obrigatória para o legislador, para ele em primeiro lugar e para êle especialmente, resulta da natureza e da extensão do princípio da igualdade perante a lei. Seria, de outra maneira, um princípio supérfluo, ou destituído de qualquer significação" ${ }^{88}$ Seabra Fagundes advoga a mesma posição, em artigo que já é um clássico do Direito Constitucional Brasileiro, aduzindo ser o princípio da igualdade um limite externo a toda atuação do poder público, uma vez que

"o cânone da igualdade perderia por inteiro a sua significação (...) se o Poder Legislativo o pudesse desconhecer. As desigualdades näo nasceriam eventualmente de atos administrativos ou sentenças, mas se multiplicariam a critério do órgão legiferante, exatamente aquele que, pelo largo alcance dos seus atos quanto às pessoas, maior número de situações pode afetar com tratamento discriminatório." 89

Ainda, na doutrina pátria, Pontes de Miranda ${ }^{90}$ assegurou ser o princípio da igualdade imperativo para o legislador, a par dos executores administrativos ou

85 Constituição Imperial, art. 179, inciso XII: “A Lei será igual para todos, quer proteja, quer castigue, e recompensará em proporção dos merecimentos de cada um."

86 “Todos sāo iguais perante a lei. Não haverá privilégios, nem distinçōes, por motivo de nascimento, sexo, raça, profissão própria ou dos pais, classe social, riqueza, crenças religiosas ou idéias políticas." Art. 113, item I.

87 In: Direito Constitucional, Vol. II. Livraria Freitas Bastos, São Paulo, 1956.

88 CAMPOS, Francisco. Nota 87, p. 18. Ver, também, Luís Afonso da SILVA. Curso de Direito Constitucional Positivo, $12^{2}$ edição. Malheiros Editores, São Paulo, 1996, pp. $210 / 211$.

89 FAGUNDES, Seabra. O Princípio constitucional da igualdade perante a Lei e o Poder Legislativo. Revista Forense, vol. 161, ano 52, setembro-outubro de 1955, Rio de Janeiro, p. 7.

90 Nota 12, p. 487. 
judiciais, bem como exerce função "insuprível": 1) regular a feitura das leis, submetendo o direito à exigência de ser igual para todos; 2) quanto ao direito já feito, a) servir de regra de interpretação, b) ser fonte de direito em si-mesmo, preenchendo as lacunas das leis anteriores ou posteriores à sua ação, c) ser preceito de direito intertemporal e de ordem pública, d) servir de regra de exegese ou interpretação da própria Constituição, "e) ser fundamento de outros princípios, só ou em conjunção com outros direitos fundamentais" (grifos nossos).

A regra da igualdade, assim concebida, prescreve a exclusão de qualquer discriminação arbitrária, entendo-se esta a que não é plenamente justificada. Mas o que justifica a discriminação? A natureza das coisas ou critérios subjetivos? A única resposta possível é a de que existem diferenças relevantes e irrelevantes entre os homens e a inserção em uma ou outra categoria depende de um juízo de valor prévio, que é, sempre, historicamente condicionado. $O$ conteúdo do princípio isonômico consistirá, então, precisamente nisto: "na determinação do nível de abstratividade que deve ter o elemento diacrítico para que ele atinja as finalidades a que a lei se preordena" ${ }^{91}$ ou, melhor dizendo, a estrutura interna do princípio implica que o critério que sirva de base para o juízo de qualificação "encontre sua justificação no fim a atingir com o tratamento jurídico".$^{92}$ A conexão entre o critério de discriminação e a finalidade da norma deverá ser razoável e suficiente, e o elemento discrímen não é autônomo em relação ao elemento finalidade. Pelo contrário, é uma decorrência e tem de ser escolhido em função deste. "Assim, ensina Celso Ribeiro Bastos, uma vez definida a finalidade, o discrímen há de ser aquele que delimite com rigor e precisão quais as pessoas que se adaptam à persecução do telos normativo",,$^{93}$ que é diverso em cada momento histórico: distinções que, em épocas passadas eram tidas como razoáveis, hoje são tidas como arbitrárias ou inconcebíveis.

A título de comparação, vale dizer, ainda, que atualmente, no Direito Alemão e Português, além da proibição de arbitrariedade, agrega-se à aplicação do Princípio da Igualdade à exigência de proporcionalidade, isto é, de adequação, necessidade, ponderação e proibição do excesso - medida de valor a partir da qual se procede a uma ponderação. ${ }^{94}$

" $O$ juizo de proporcionalidade é um juizo jurídico, ancorado na correcta interpretação e aplicação das normas e na adesão aos valores que lhes subjazem; não é um juízo meramente cognoscitivo; com ele, cura-se de uma funcionalidade teleológica, não de qualquer funcionalidade lógica ou semântica"..$^{9}$

Partindo dessas considerações, Canotilho" constata existir uma violação arbitrária da igualdade jurídica, quando a discriminação veiculada na norma não se basear: a) em um fundamento sério; b) não tiver sentido legítimo e c) estabelecer

91 BASTOS, Celso Ribeiro. Nota 22, p. 167.

92 FERREIRA PINTO, M. Nota 7, p. 46.

93 Nota 22, p. 168.

94 Ver MIRANDA, Jorge. Nota 1, p. 216; HECK, L.A. Nota 83, pp. 176/177 e p. 226.

95 MIRANDA, J. Nota 1. p. 219.

96 Nota 12, p. 656. 
diferenciação jurídica sem um fundamento razoável. Heck, ${ }^{97}$ a seu turno, assevera, segundo a ótica da jurisprudência do Tribunal Constitucional Federal Alemão, ser o preceito da igualdade geral violado quando:

"a) (...) um fundamento razoável, resultante da natureza da coisa ou de outro modo objetivamente elucidativo, não se deixa encontrar para a diferenciaçäo ou para o tratamento igual legal, em suma, quando a determinação precisa ser caracterizada como arbitrária; b) (...) o tratamento desigual dos fatos regulados não é mais compativel com um modo de ver orientado por idéias de Justiça, ou seja, quando falta um fundamento elucidativo para a diferenciação legal; c) (...) a diferenciafão realizada por uma lei não se deixa reconduzir a um fundamento razoável ou de outra maneira elucidativo; d) (...) um grupo de destinatários normativos, em comparação com outros destinatários normativos, é tratado de forma diversa, embora não haja, entre ambos os grupos, nenhuma diferença de tal arte e de tal peso que pudesse justificar tratamento distinto; e) (...) o legislador falta, ou omite, à consideraf̧ão a igualdades ou a desigualdades reais das relações da vida a serem ordenadas, as quais são tanto significativas que precisam ser observadas em um modo de ver orientado por concepfões de Justiça".

Quanto ao direito brasileiro, a fim de que as leis, pelo seu conteúdo, não firam a igualdade constitucionalmente garantida, é necessário existir um vínculo lógico entre a discriminação estabelecida e a finalidade a que a lei se destina: é lógico e aceitável que se use o critério sexo para o preenchimento do cargo de guarda penitenciário de um presídio para homens, assim como não é lógico, nem aceitável que este mesmo critério sirva para selecionar candidatos ao cargo de juiz. De outra parte, o critério discriminador tem de estar em consonância com os interesses absorvidos no sistema constitucional e destarte juridicizados. Assim, por exemplo, se um dos objetivos fundamentais da República do Brasil é promover o bem de todos, sem preconceitos de origem, raça, sexo etc., quaisquer destes elementos não podem ser eleitos critérios de distinção. No exemplo do guarda penitenciário, aceitava-se o sexo como fator de discriminação, mas não se aceitará que a seleção leve em conta a origem dos candidatos (quer seja origem social, cultural ou econômica) ou a sua raça. Por fim, um terceiro parâmetro, complementar aos demais, é o fato de que as discriminações deverem manter a generalidade e a abstração própria dos atos legislativos ou seja, se a norma singularizar atual e definitivamente um destinatário determinado, ao invés de abranger uma categoria de pessoas, ou uma pessoa futura e indeterminada, haverá ofensa ao preceito constitucional da igualdade. ${ }^{98}$

\section{B - A extensão do Princípio da Igualdade no Direito Brasileiro}

A Carta Política em vigor no Brasil, promulgada em 05 de outubro de 1988, assevera, em seu artigo 3², serem objetivos fundamentais da República: "construir uma sociedade livre, justa e solidária" (inciso I), "erradicar a pobreza e a margi- 
nalização e reduzir as desigualdades sociais e regionais" (inciso III) e "promover o bem de todos, sem preconceitos de origem, raça, sexo, cor, idade e quaisquer outras formas de discriminação" (inciso IV), elevando a valor supremo do Estado tanto a igualdade formal quanto a material, proibindo, de antemão, discriminações arbitrárias. O princípio da igualdade tem posição proeminente no sistema constitucional brasileiro: penetra, informa, dá conteúdo aos demais direitos e garantias constitucionais, não sendo aleatório que o art. 59, caput, da CF de 1988 - "Todos são iguais perante a lei, sem distinção de qualquer natureza, garantindo-se aos brasileiros e estrangeiros residentes no País a inviolabilidade do direito à vida, à liberdade, à igualdade, à segurança e à propriedade, nos termos seguintes:" enuncie " $\mathrm{a}$ isonomia antes mesmo e à frente da discriminação dos direitos e garantias fundamentais que institui". .9

Consoante esse dispositivo constitucional, se agrega a própria igualdade como um dos direitos que a lei deve garantir a todos igualmente, encampando-se, além da igual aplicação da lei, um conteúdo igual da legislação. A isonomia vem concebida como um dos conteúdos necessários da legalidade, inexistindo a igualdade com um dado social reconhecido à posteriori pela Constituição. "Se assim não fora, não seria ela igualdade no sentido jurídico-positivo. É dizê-la uma instituição normativa. Uma legalidade isônoma". ${ }^{100}$ A sequiência dos dispositivos revela ser esta legalidade isonômica explicitamente referida na Carta Magna, pois o inciso I do art. $5^{\circ}$ dispõe serem "homens e mulheres são iguais em direitos e obrigações, nos termos desta Constituição", e o inciso II, que "ninguém será obrigado a fazer ou deixar de fazer alguma coisa senão em virtude de lei". Assim, o próprio conteúdo da lei, ao outorgar direitos e impor obrigações, deve manter a igualdade preconizada entre homens e mulheres. A igualdade assim consagrada ultrapassa a mera aplicação isonômica do princípio para determinar que o conteúdo da lei, conferindo direitos e obrigações, apanhe semelhantemente homens e mulheres. Destarte, a concepção doutrinária de ser o legislador também destinatário do princípio da igualdade recebeu acolhimento constitucional. E mais: a Constituição esclarece em que consiste o igual tratamento, bem como dá os seus limites, isto é, caracteriza as discriminações que são constitucionalmente toleradas e as que não o são, ao complementar o enunciado do princípio da igualdade, com a seguinte expressão: "sem distinção de qualquer natureza". A lei, assim, "deve incluir a igualdade, a indistinção "de qualquer natureza" como um conteúdo seu, um componente material e pessoal do seu âmbito de validade normativa". ${ }^{101}$ José Afonso da Silva aponta ser esta expressão uma escolha do legislador constituinte - vedando distinções de qualquer natureza e qualquer forma de discriminação - por ser suficientemente abrangente "para recolher também aqueles fatores que têm servido de base para desequiparações e preconceitos", tais como o

99 BORGES, José Souto Maior. Princípio da Isonomia e sua significaf̧ão na Constituição de I988, RDP, n² 93, 1990, p. 34.

100 BORGES, J. S. M. Nota 99, p. 35.

101 BORGES, J. S. M. Nota 99, p. 37. 
fator orientação sexual, assegurando a liberdade das pessoas de ambos os sexos de adotarem a orientação sexual que melhor lhes aprover. ${ }^{102}$

O Princípio da Igualdade não é, como se vê, apenas declarado na Constituição da República: é aplicado em todos os campos considerados importantes segundo a idéia de Direito que a perpassa, isto é, de acordo com todos os valores ali consubstanciados, frutos de um consenso conquistado a duras penas pelos brasileiros, durante os trabalhos da Assembléia Constituinte de 1987. Assim, são corolários imediatos ${ }^{103}$ do princípio da igualdade: a regra do sufrágio igual, nos termos da lei (art. 14); a aplicação da lei penal de conteúdo mais favorável, ainda que retroativa (art. 52, XL); a igualdade entre os cônjuges ou equiparados para este efeito (parágrafo $5^{\circ}$, art. 226), entre os filhos (parágrafo $6^{\circ}$, art. 226); a não privação de direitos por causa de convicções ou práticas religiosas (art. 5e, VIII), a igualdade no acesso à função pública, em regra por via de concurso (art. 37, 1); contratação com o serviço público, em igualdade de condições, assegurada por processos de licitação (art. 37, XXI) e a igualdade de acesso a quaisquer cargos, trabalhos ou categorias profissionais (art. $5^{2}$, XIII).

No que tange à igualdade como proporcionalidade, isto é, relativa às distinções correspondentes a diferença de situações, temos: a atribuição, fora dos períodos eleitorais, aos partidos políticos, de tempos no rádio e televisão, na forma da lei (de acordo com sua representavidade) (art. 17, parágrafo $3^{2}$ ); proteção adequada dos representantes eleitos dos trabalhadores (art. 8, VII); a especial proteção do trabalho das mulheres durante a gravidez e o parto, bem como dos menores e das atividades em condições insalubres, perigosas ou penosas (art. 7², incisos XVIII, XX, XXIII, XXXIII); proteção das condiçōes de trabalho e a garantia dos benefícios sociais os trabalhadores avulsos (art. 70, XXXIV); proteção das crianças órfãs e abandonadas (art. 227, parágrafo 32, VI) e dos jovens trabalhadores (art. 227, parágrafo 3ㄹ, I, II e III); tratamento preferencial, na aquisição de bens e serviços, nos termos da lei, à empresa brasileira de capital nacional (art. 171, parágrafo $2^{2}$ ).

Por outro lado, são exemplos de imposições de igualdade social: o acesso gratuito ao Poder Judiciário pelos que comprovarem insuficiência de recursos (art. 5e, LXXIV); proteção do mercado de trabalho da mulher, mediante incentivos específicos, nos termos das leis (art. 7, XX); garantia de um serviço nacional de saúde tendencialmente gratuito, tendo em conta as condições econômicas dos cidadãos (art. 193, 194, 195 e 196); a promoção da democratização da educação e da cultura (arts. 205 e 215); orientação do desenvolvimento econômico e social no sentido de um crescimento equilibrado e da erradicação da pobreza, marginalização è das desigualdades sociais e regionais (art. 32, III; 170, VII; 174 e 193).

Finalmente, temos as discriminaf̧ões positivas, relacionadas com essas imposições e outros deveres do Estado, tais como: a proteção especial dos jovens trabalhadores (art. 227, parágrafo $3^{2}$, I, II e III); condiçōes mais favoráveis e apoio prefe-

102 Nota 88, p. 218.

103 A "classificação" ora proposta é baseada na apresentada por Jorge MIRANDA, nota I, Tomo IV, pp. 209/210, por acreditarmos ser bastante elucidativa. 
rencial às cooperativas e a outras formas de exploração coletiva por trabalhadores (art. 174, parágrafos $2^{\circ}, 3^{\circ}$ e $4^{\circ}$ ).

Assim, alguns destes corolários do Princípio da Igualdade podem ser direitos especiais de igualdade ou podem ser reconduzidos a direitos, liberdades e garantias. Da mesma forma, do postulado da igualdade social podem decorrer direitos econômicos, sociais e culturais, indicando ser a conquista da igualdade mais uma ação concreta do que uma mera declaração abstrata, através da eliminação ou redução das desigualdades. $O$ jurista português Jorge Miranda, em valiosa lição para nós, brasileiros, sintetiza muito bem a questão ao assegurar ser a conquista da igualdade fruto "quer da difusão das idéias quer das lutas pela igualdade travadas por aqueles que se encontravam em situações de marginalização, opressão e exploração", assim como

"que, embora a superação destas ou daquelas desigualdades nunca seja definitiva e, por vezes, até venha acompanhada do aparecimento de novas desigualdades, o ideal de uma sociedade alicerçada na igualdade (ou na justiça) é um dos ideais permanentes da vida humana e um elemento crítico de transformação não só dos sistemas jurídicos mas também das estruturas sociais e políticas" ${ }^{104}$

Outra não é a posição de Pontes de Miranda, ${ }^{105}$ para quem o movimento igualitário é tão essencial do direito contemporâneo, que se revela nas leis constitucionais e ordinárias como uma tríade - igualdade política, igualdade jurídica e igualdade econômica. E esta, a desigualdade econômica, "não é, de modo nenhum, desigualdade de fato e sim a resultante de simples desigualdades artificiais, ou de desigualdades de fato mais desigualdades econômicas mantidas por leis. $\mathrm{O}$ direito, que em parte as fez, pode aparar e extinguir as desigualdades econômicas que produziu" (grifamos). A igualdade política, a seu turno, seria "realizada pela técnica da democracia", isto é, pelo sufrágio universal e pela inexistência de privilégios políticos. "Liberdade, e responsabilidade dos governos; igualdade e justiça distributiva; democracia, e respeito às leis: esse é o sentido da evolução humana", ${ }^{106}$ finaliza o mestre.

\section{Conclusão}

Atualmente, nos países de tradição jurídica continental (na qual o Brasil se inclui), é indiscutível serem as idéias de liberdade e igualdade os valores superiores dos ordenamentos jurídicos, tais como vêm concebidos e representados nas diversas Constituições, isto é, como conteúdo material da Justiça e do pluralismo político. Os assim chamados "direitos de liberdade e igualdade" pretendem, em última instância, facilitar e tornar possível o desenvolvimento integral da pessoa e o exercício efetivo e real de sua dignidade. ${ }^{107} \mathrm{~A}$ análise da evolução do princípio da

104 Nota 1, Tomo IV, p. 204.

105 Nota 12 , pp. 462 e ss.

106 Nota 12, p. 552.

107 Cf. PECES-BARBA, Gregório. Nota 17, p. 36/38. 
igualdade, feita até aqui, seu conteúdo, desdobramentos e direçōes, permite-nos concluir, seguindo as lições de Castanheira Neves e Canaris, ${ }^{108}$ ser este um princípio fundante e estruturador de toda a ordem jurídica ou sistema jurídico, pois um sistema é o que for sua unidade e não só a constitui, como também instaura (ou pretende instaurar) uma estabilidade e uma continuidade. Esta unidade e ausência de contradição, que implica coerência, é para o Direito uma exigência normativa, postulada pelo Princípio da Igualdade: assegura-se com a unidade e a ausência de contradição da lei, a igualdade de sua aplicação, e isto está diretamente ligado com os valores certeza e segurança. O Princípio da Igualdade é, por assim dizer, a expressão do princípio da Justiça e a afirmação da idéia de Direito, exigindo a racionalidade de uma ordem como a "unidade da não contradição normativa". Nestes termos, da regra de justiça - princípio da igualdade - resulta o sistema jurídico, que é nada mais que o ordenamento axiológico e teleológico dos princípios gerais do direito, no sentido de realização destes valores concretizados em diferentes níveis. ${ }^{109}$

Constatou-se, ainda, ser a igualdade material, ou de conteúdo - "na lei" - o programa constitucional de mais difícil realização, por não ser um dado de fato, mas um ideal a ser permanentemente concretizado, face às intrínsecas desigualdades existentes entre os homens. A direção mais completa do princípio da igualdade em direitos e obrigações é, nos dias atuais, a que preconiza a igualdade entre os gêneros, por ser uma regra que resume décadas de lutas das mulheres contra discriminações.

Assim, quando os entes comparados são homens e mulheres e o critério diferenciador é o gênero, que tratamentos são proibidos ou permitidos? A resposta é bastante complexa e demanda uma investigação mais apurada e completa, pois as leis igualitárias não são suficientes "para extirpar as discriminações e os vícios nas relações de gênero, profundamente enraizados na sociedade". ${ }^{110} \mathrm{O}$ Direito Privado, por exemplo, foi historicamente construído para regular as relações dos homens e seus bens, isto é, constitui uma regulação objetiva da propriedade e da família. No contexto da família, a mulher foi inferiorizada, sendo o casamento monogâmico, na concepção de Engels," "' a primeira divisão de trabalho e o primeiro antagonismo de classe surgido na história da humanidade.

As transformações econômico-sociais do final do séc. XIX e início deste, além de determinarem um novo tipo de sociedade e de Estado, refletiram-se em profundas modificações no Direito de Família dos povos ocidentais, ${ }^{112}$ do ponto de vista material, patrimonial e pessoal, isto é, no regime de bens, nas relações entre pais e

108 CASTANHEIRA NEVES, Antonio. A unidade do Sistema Juridico: o seu problema e o seu sentido (Diálogo com Kelsen) Boletim da Fac. Direito de Coimbra, volume em homenagem ao Prof. J. J. Ribeiro; CANARIS, Wilhelm Claus. Nota 17.

109 Cf. CANARIS, nota 17, p. 97.

110 VERUCCI, Floriza. A Eficácia do Direito Igualitário nas Relaçōes de Género. Revista Brasileira de Estudos Políticos $\mathrm{n}^{2}$ 72. Universidade Federal de Minas Gerais, Belo Horizonte, janeiro de 1991, p. 147. 111 ENGELS, Friedrich. A origem da Familia, da Propriedade Privada e do Estado. Civilização Brasileira, $3^{3}$ ed. Rio de Janeiro, 1977, pp. 58 a 66.

112 Ver MICHEL. Andrée. Modèles sociologiques de la famille dans les sociétés contemporaines. Archives de Philosophie du Droit. № 20 (réformes du droit de la famile), Sirey, Paris, 1975, pp. 127/135. 
filhos, na equiparação dos filhos (legítimos, ilegítimos, adotados), e, principalmente, nas relações entre os cônjuges, pois a progressiva emancipação feminina colocou o problema da igualdade. No Brasil, o sufrágio feminino foi obtido em 1932 e, no âmbito constitucional, em 1934, mas o movimento das mulheres em direção à igualdade plena renasceu e se vitalizou a partir da abertura política dos anos 70 , seguindo as linhas de força históricas da década de 60 , tais como a revolução sexual e liberalização dos costumes, que preconizaram, basicamente, a necessidade de transcender a determinação do sexo como base dos papéis sociais, pois trabalho e família, "embora pertençam a esferas distintas, são igualmente importantes tanto para o homem quanto para a mulher". ${ }^{113} \mathrm{O}$ prińcípio básico passou a ser a responsabilidade compartilhada entre os gêneros, na criação dos filhos e nos trabalhos daí decorrentes. A igualdade assegurada constitucionalmente não basta, contudo: os códigos e as leis têm de ser alterados, submetidos à Carta Política, pois que ainda tratam, nos seus textos, da mulher de forma injusta ou obsoleta, principalmente o Código Penal. Constata-se, entretanto, uma lenta e progressiva alteração no que tange às exigências morais - de comportamento - estabelecidas às mulheres, nas decisões judiciais relativas aos processos de família, em que se discutem guarda de filhos e regime de bens. ${ }^{114}$

Destarte, quando a comparação é entre homens e mulheres perante a Ordem Jurídica, ressalta que o campo principal das desigualdades é o do Direito Civil regime de bens e guarda e educação dos filhos, ${ }^{115}$ ainda mais considerando-se ser o casamento ou a união livre dos gêneros, nos dias atuais, pertencente à esfera da privacidade e não mais do patrimônio. ${ }^{116}$ Como os diversos ordenamentos jurídicos,

113 VERUCCI. Nota 110 , p. 151.

114 Ver, sobre isso, o valioso trabalho de Silvia PIMENTEL, Beatriz DI GIORGI \& Flávia PIOVESAN: A Figura/Personagem Mulher em Processos de Familia. Sérgio Antonio Fabris Editor, Porto Alegre, 1993. "A ideologia dominante patriarcal, que admite a subalternidade social e política da mulher, é a maior responsável pela diferenciaçāo de papéis sociais em função do gênero, e os valores androcêntricos - ainda hoje dominantes, mas progressivamente questionados - sāo os determinantes fundamentais das exigências morais estabelecida às mulheres. Este pressuposto levou à seguinte hipótese: os valores patriarcais se reproduzem sob a forma de esteriótipos e de preconceitos no interior do processo, a partir do discurso dos agentes processuais. Tal reprodução dá-se, muitas vezes, de forma mecânica", p. 21 .

115 Ver sobre isso: FURKEL, Françoise. De la Dernière Discrimination des Sexes en Allemagne: La Responsabilité parentale dans da Filiation Naturelle et en Cas de Désuninon du Couple Marié. Revue Internationale de Droit Comparé. N2 3, 1992, pp. 609/639; VINEY, Geneviève. Du "Droit de Visite". Revue Trimestrielle de Droit Civil. Sirey, Paris, 1965, pp. 225/260; FERRAND, Frédérique. Le Droit Civil de la Famille et L'Égalité des Époux en Republique Fédérale D'Allemagne, RIDC, n² 3, 1986, pp. 868/892.

116 Ver: MEULDERS-KLEIN, Marie-Thérese. Vie Privée, Vie Familiale et Droits de L'Homme, RIDC, $\mathrm{n}^{2}$ 4, 1992, pp. 767/794; TABORDA, Wilmar Corrêa. O casamento romano do direito clássico e as uniōes livres da Constituição Brasileira de 1988. Dissertação de conclusão apresenta para obtenção do título de especialista em Direito Romano. PUC-RS, agosto de 1995 (“As uniōes entre homem e mulher sem o vínculo do casamento revelaram-se no Brasil um fato social tão marcante, principalmente a partir da década de 80, que o Estado, através da Constituição de 1988, entendeu de protegêe-las "enquanto forma de família e como instituto que tem conseqüências jurídicas". (...) Por isso, nos modernos sistemas jurídicos uniformiza-se a tendência de interferir o menos possível na privacidade, nas relaçōes íntimas 
e mesmo o brasileiro, resolvem estas questões poderia ser objeto de uma investigação mais apurada, que ainda está por se fazer no Brasil. Em relação ao regime de bens, valiosa é a lição de Clóvis do Couto e Silva. ${ }^{117}$

“A secularização do casamento, proveniente da revolução francesa, não teve a virtude de transformar o "status" da mulher submetida como ficou ao poder marital até data recente. Mas a revolução industrial ao mobilizar massas de agricultores para as cidades, e ao criar, com a industrialização, a nova civilização urbana, teve a virtude de fazer com que a mulher pudesse aos poucos administrar os bens que lhe pertenciam".

No que concerne à consideração das relações entre homens e mulheres pertencerem, exclusivamente, à esfera da privacidade e intimidade, o legislador infra-constitucional brasileiro vem encontrando dificuldades, porquanto as leis ${ }^{18}$, recentemente promulgadas, disciplinando as uniões estáveis, na forma do art. 226, parágrafo $3{ }^{\circ}$, da Constituição Federal, ainda confundem os planos patrimonial e pessoal destas relações quando dispõem, por exemplo, ser obrigatória a comunhão parcial de bens se o "casal" de outra forma não dispuser. ${ }^{19}$ Conclui-se, assim, pela importância capital de uma adequada construção doutrinária, legal e jurisprudencial no tratamento da igualdade entre homens e mulheres no direito brasileiro.

do cidadāo e, concomitantemente, acentua-se a concepção de pensar-se a família como uma forma plural, a exemplo do artigo 226, parágrafo 40, da Constituição Brasileira"), pp. 50/51.

117 In: Direito Patrimonial de Família. Separata da Revista da Faculdade de Direito e Porto Alegre, UFRGS, ano $\mathrm{V}, \mathrm{n}^{2} 1, \mathrm{p} .51$.

118 Lei 8.971/94 e Lei 9.278/96.

119 Art. 59, Lei 9.278/96. 


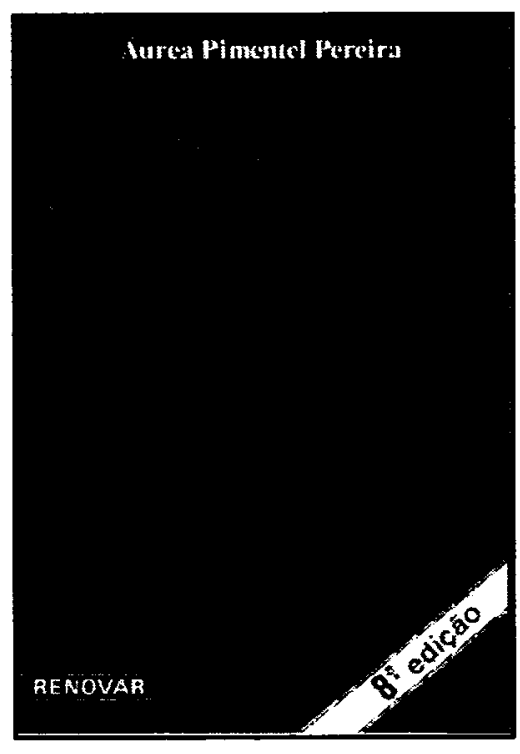

\section{Ref. 0013 \\ Brochura \\ 216 págs. \\ Form. 14x21 \\ 1994}

\section{DIVÓRCIO E SEPARAÇÃO JUDICIAL}

Áurea Pimentel Pereira

Esta obra é de grande utilidade para os profissionais e interessados em Direito de Familia. A autora, em linguagem clara, comenta, artigo por artigo, a Lei do Divórcio, apontando suas alteraçōes decorrentes da Constituição de 1988. Os aspectos controvertidos são abordados, com especial cuidado, unindo a longa experiência da autora, que muitas vezes diverge de outros comentadores, mas justifica seu entendimento e cita doutrina e jurisprudência, inclusive de direito comparado. 